\title{
Field and Modeling Study on Saving Mineral Fertilizers, Increasing Farm Income and Improving Soil Fertility Using Bio-Irrigation with Drainage Water from Fish Farms
}

\author{
Abdelraouf R. E. ${ }^{1, *}$, Ayman El-Sayed ${ }^{2}$, Ibrahim A. Alaraidh ${ }^{3}$, Abdulaziz Alsahli ${ }^{3}$ \\ and Mohamed El-Zaidy ${ }^{3}$ \\ 1 Water Relation and Field Irrigation Dept., National Research Centre 33 El-Bohouth St., (Formerly El-Tahrir St.), \\ Dokki, Cairo 12622, Egypt \\ 2 National Water Research Center (NWRC), Drainage Research Institute (DRI), NWRC Building, \\ P.O. Box 13621/5, El-Qanater El-Khiriaya, Egypt; aymanawad1@yahoo.com \\ 3 Botany \& Microbiology Department, Science College, King Saud University, P.O. Box 2455, Riyadh, Saudi Arabia; \\ ialaraidh@ksu.edu.sa (I.A.A.); aalshenaifi@ksu.edu.sa (A.A.); melzaidy@ksu.edu.sa (M.E.-Z.) \\ * Correspondence: abdelrouf2000@yahoo.com
}

Received: 22 August 2020; Accepted: 21 October 2020; Published: 26 October 2020

check for updates

\begin{abstract}
The reuse of new and non-traditional sources of water for the purpose of irrigation is the primary goal of all countries that are located in dry areas and suffer from water scarcity, including Egypt in particular. This study was conducted to determine the appropriateness and quantify the benefits of using fish farm wastewater (DWFF), as an alternative to fresh irrigation water (IW), for the irrigation of barley. Two types of water quality were tested for the irrigation of barley, namely DWFF and IW, in addition to four levels of fertilization rates, $100 \% \mathrm{~N}, 80 \% \mathrm{~N}, 60 \% \mathrm{~N}$, and $40 \% \mathrm{~N}$, where $100 \% \mathrm{~N}$ represents $156 \mathrm{~kg}$ of nitrogen per hectare. The results showed a positive effect of increasing the nitrogen fertilization rate with irrigation water on the crop with the use of DWFF and IW for irrigating barley in two seasons: 2017/2018 and 2018/2019. The yield when using DWFF for the irrigation of barley was higher than the yield when using IW, which was in the range of $5.1 \%$ and $25.9 \%$ in $2017 / 2018$ and between $9.8 \%$ and $33.3 \%$ in 2018/2019. This was due to the additional amount of dissolved biological nitrogen and other nutrients contained in DWFF. Notably, an additional amount of dissolved nitrogen is inherent in DWFF (12.81 kg nitrogen ha ${ }^{-1}$ in 2017/2018 and $12.43 \mathrm{~kg}$ nitrogen $\mathrm{ha}^{-1}$ in 2018/2019) and other elements, such as phosphorus and potassium, which are two macronutrients for crops. The SALTMED model was used to simulate soil moisture content, water application efficiency, nitrogen concentration in the soil layer in the effective root zone, $\mathrm{N}$ uptake, the dry matter of grown barley, and yield and water productivity for all treatments, with $\mathrm{R}^{2}$ values of $0.94,0.89,0.99,0.916,0.89,0.915$, and 0.919 respectively. The research concluded that the use of DWFF is an effective alternative to IW for irrigating barley. It also helped to achieve higher yields while applying lower amounts of IW and chemical fertilizers. There are also additional benefits, such as reducing the drainage to the drainage network and increasing the income of farmers.
\end{abstract}

Keywords: drainage water; fertigation technology; fish farms; Nuptake; yield; barley; SALTMED model

\section{Introduction}

Arid regions are generally characterized by having high population densities and limited fresh water available. These factors put substantial pressure on the agricultural sector to reduce the consumption of limited amounts of fresh water for irrigation to allow water to be available to other 
essential sectors [1-3]. Water scarcity is one of the serious challenges facing the cultivation and production of crops in dry areas. Therefore, it is important to rationalize and reduce the consumption of IW by developing in novative irrigation technologies that are effective at conserving water $[4,5]$. In Egypt, the agricultural sector faces the challenge of increasing food production using less water. This can be achieved by increasing the crop yield per unit of water. Increasing the productivity of crops per unit of water is vital under conditions of water scarcity to meetthe increasing demand for food resulting from increases in the rate of population growth [6,7]. Egypt is suffering from severe water scarcity, and competition for scarce water resources is increasing as new irrigation techniques are being used to increase the productivity and quality of cultivated crops [8]. In the Arab Republic of Egypt, where average rainfall is very low, the productivity of crops per unit of water is very important [9]. The average annual rainfall is $12 \mathrm{~mm}$, and it ranges from $0 \mathrm{~mm}$ per annumin the desert regions to $200 \mathrm{~mm}$ per annumin the north coastal regions. In addition, the maximum total volume of rain does not exceed 1.8 billion $\mathrm{m}^{3}$ per year [10]. The use of micro irrigation and related techniques should be promoted in arid regions, such as Egypt, to use a portion of IW to cultivate new areas [11-13].

Meanwhile, to meet the increasing demand for protein, aquaculture has been started in many semi-arid countries. Obviously, given the concerns for water resources in arid and semi-arid regions, increases in the number of aquaculture operations is exacerbating the problem of water availability for this purpose [14]. Over centuries, traditional farmers have developed diverse, locally adapted farming systems, which have been managed through ingenious practices that have often provided community food security and preserved agro-biodiversity [15]. It was found that the rice yield did not decline when fish production was below a threshold value in rice and fish intensive systems. Moreover, fish yields in intensive rice and fish systems can be much higher than those in traditional rice and fish systems without reducing the rice yield. In addition, the use of fertilizers, nitrogen $(\mathrm{N})$, and pesticides has decreased, and the net income of farmers has increased [16,17]. However, new fish farms have contributed significantly to the food supply [18]. Nevertheless, to maintain the sustainability of IW, it may be necessary to focus on sustainable and integrated systems in which organic waste is used as an input for a different agricultural activity [19]. This can be achieved by establishing fish farming, in arid and semi-arid areas, that uses flushing irrigation ponds. In this context, the Food and Agriculture Organization FAO [20] reported on "Integrated Irrigated Agriculture" in which the productivity of the crop per unit of water can be improved by producing and raising fish in irrigation channels and re-using that water to irrigate agricultural crops. In addition, fish can be grown in slightly salty wastewater, which couldpossibly be used to irrigate crops. When fish farms are prohibited from keeping fish in irrigation canals, fish can be raised in water storage tanks. Then, water can be used for irrigation when it is time to change and drain those [21]. Fish ponds have additional functions: they attract wildlife and can be used for recreational activities and storing water that is used for irrigation. Fish can also be raised in tanks equipped for hydropower and irrigation. Some of the risks of this approach are that the fishes' environment may be adversely affected as the water level inside the water tanks changes when it is used for irrigation [22]. However, this approach is being used in the Czech Republic and elsewhere, where large fish farm ponds are an integral part of the natural environment [23].

In addition to being a water source for irrigation, wastewater from fish farms is a good source of organic materials, and minerals from wastewater can improve soil quality, yield and crop quality, and reduce the cost of purchasing chemical fertilizers. Simultaneously, the content of organic matter (OM) in fish farm wastewater improves the ability of sandy soils to conduct cation exchange, thus providing cultivated plants with nutrients. Better growth of plants is expected when their roots absorb the dissolved nutrients excreted by fish and microbially decomposed organic waste [24].

The model of SALTMED by [25] is consideredone of the most important models that have been developed, and it has proven its ability to simulate many crops under various field administrations, accounting for different irrigation systems, water characteristics, irrigation strategies, types of soils, crops, drainage systems, and fertilizer applications, and the effects of abiotic stresses, such as drought, salinity, extreme temperature, and shallow groundwater. 
The current version of the model, which was released in 2015 , allowed simultaneous simulations of 20 fields each with different irrigation systems, soils, crops, irrigation strategies, and $\mathrm{N}$ fertilizers. This model simulates soil moisture, dry matter, crop productivity, soil salinity, soil nitrogen dynamics, the requirements for salinity filtration, nitrate filtration, and drainage, soil temperature, evaporation, water absorption, water salinity, groundwater level, and effluent flow. This model was calibrated and validated using observed field data by [26-37]. They demonstrated the high predictability of field-measured yield, soil moisture, dry matter, and salinity.

This studyaimed to determine the suitability and maximum benefit ofusing fish farm drainage water to reduce the need formineral fertilizers and the total costs of production requirements in addition to improving soil fertility under dry conditions in Egypt through a field study and modeling using the SALTMED model.

\section{Materials and Methods}

\subsection{Location and Climatic Data of the Experimental Site}

Field experiments were conducted during the winter season of 2017/2018 and 2018/2019 at the research farm of the National Research Centre (NRC) (latitude 30³0'1.4' N, longitude 30 19'10.9' E, and $21 \mathrm{~m}$ above mean sea level at Nubaryia Region, Al Buhayrah Governorate, Egypt. The experimental area has an arid climate with cool winters and hot dry summers. The maximum and minimum temperature, relative humidity, and wind speed were obtained from the local weather station at El-Nubaryia Farm, as shown in Figure 1 and Table 1.

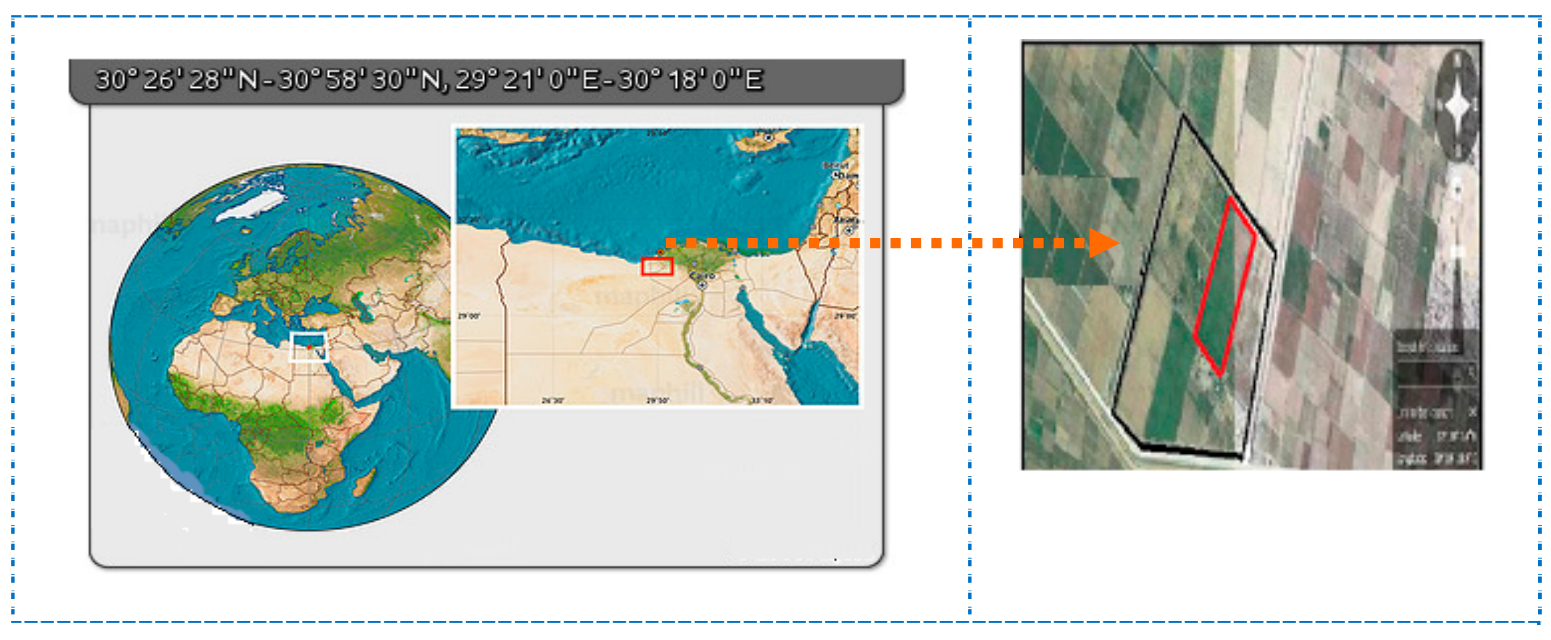

Figure 1. Area of the experimental site.

\subsection{Chemical and Physical Properties of the Studied Soil and Water Quality of Two Types of Irrigation}

The primarychemical and physical properties of the soil samples were identified and measured in situ and in the laboratory at the start of the field experiment (Table 2). The average values for the chemical, physical, and biological properties of fresh IW and fish farm wastewater were also measured, particularly during the effective period of barley fertilization, when a sample was taken every week until the number of samples reached seven samples during that period. The results for the analysis of the samples of fresh IW and DWFF showed that there were no significant differences between the fresh IW samples during the sampling period (effective fertilization period), while there were significant differences between the fish farm wastewater samples. These findings would be expected for differentin fish activity, feeding, and temperature, which change the content of this water from the dissolved elements, organic components, algae, and other vital components (Tables 3 and 4). 
Table 1. Meteorological data for the research farm of the National Research Center (NRC) in Nubaryia.

\begin{tabular}{|c|c|c|c|c|c|c|c|c|c|c|}
\hline \multirow{2}{*}{$\begin{array}{c}\text { Meteorological Data } \\
\text { Date }\end{array}$} & \multicolumn{2}{|c|}{$\mathrm{T}_{\text {MAX }}$} & \multicolumn{2}{|c|}{$\mathrm{T}_{\text {MIN }}$} & \multicolumn{2}{|c|}{ RAIN } & \multicolumn{2}{|c|}{ WIND } & \multicolumn{2}{|c|}{ RH } \\
\hline & $2017 / 2018$ & $2018 / 2019$ & $2017 / 2018$ & $2018 / 2019$ & $2017 / 2018$ & $2018 / 2019$ & $2017 / 2018$ & $2018 / 2019$ & $2017 / 2018$ & $2018 / 2019$ \\
\hline November & 24.25 & 24.38 & 12.23 & 14.35 & 0 & 0 & 3.42 & 4.13 & 58.36 & 69.17 \\
\hline December & 21.29 & 20.35 & 10.32 & 10.52 & 0 & 0 & 3.64 & 5.13 & 63.5 & 69.83 \\
\hline January & 17.61 & 18.82 & 5.97 & 8.7 & 0 & 34.48 & 3.67 & 5.33 & 61.22 & 67.83 \\
\hline February & 20.01 & 19.73 & 6.71 & 8.98 & 0 & 17.6 & 3.51 & 5.67 & 60.56 & 67 \\
\hline March & 24.05 & 21.55 & 10.13 & 10.7 & 0 & 9.63 & 4.21 & 6.12 & 51.5 & 61 \\
\hline April & 28.46 & 24.7 & 12.24 & 13.05 & 68.08 & 0 & 4.3 & 6.05 & 43.5 & 59 \\
\hline May & 33.42 & 28.15 & 16.82 & 16.23 & 0 & 0 & 4.44 & 5.45 & 39.09 & 58.33 \\
\hline
\end{tabular}

Total precipitation during the two growing seasons for barley to be deducted from the total amount of water calculated

TMAX: maximum air temperature (degrees $\mathrm{C}), \mathrm{T}_{\mathrm{MIN}}$ : minimum air temperature (degrees $\left.\mathrm{C}\right)$, RAIN: average precipitation (mm/day), WIND: wind speed (m/s), RH: average relative humidity $(\%)$. 
Table 2. Chemical and physical properties of the studied soil.

\begin{tabular}{ccccc}
\hline \multirow{2}{*}{ Parameter } & \multicolumn{4}{c}{ Soil Depth (cm) } \\
\cline { 2 - 5 } & $\mathbf{0 - 1 5}$ & $\mathbf{1 5 - 3 0}$ & $\mathbf{3 0 - 4 5}$ & $\mathbf{4 5 - 6 0}$ \\
\hline \multicolumn{4}{c}{ Physical properties } \\
\hline Textural class & Sandy & Sandy & Sandy & Sandy \\
Coarse sand (\%) & 46.74 & 55.70 & 38.75 & 36.79 \\
Fine sand (\%) & 50.78 & 40.68 & 57.44 & 59.10 \\
Silt + clay (\%) & 2.48 & 3.62 & 3.81 & 4.11 \\
BD $\left(\mathrm{t} \mathrm{m}^{-3}\right)$ & 1.68 & 1.69 & 1.69 & 1.69 \\
\hline \multicolumn{5}{c}{ Chemical properties } \\
\hline ECe $\left(\mathrm{dS} \mathrm{m}{ }^{-1}\right)$ & 0.37 & 0.33 & 0.45 \\
pH $(1: 2.5)$ & 8.6 & 8.7 & 9.1 & 0.47 \\
CaCO $(\%)$ & 7.03 & 2.35 & 4.67 & 5.05 \\
OMa $(\%)$ & 0.64 & 0.42 & 0.27 & 0.25 \\
\hline
\end{tabular}

BD: bulk density, OM:organic matter. All soil and water analyses were conducted in the laboratories of the National Research Center in Egypt.

Table 3. Some properties of drainage water from fish farms and fresh irrigation water.

\begin{tabular}{ccc}
\hline Parameter & $\begin{array}{c}\text { Drainage Water of Fish Farm } \\
\text { (DWFF) }\end{array}$ & Irrigation Canal Water (IW) \\
\hline E.C, $\mathrm{dS} \mathrm{m}^{-1}$ & 1.85 & 0.45 \\
$\mathrm{pH}$ & 8.21 & 7.38 \\
\hline & Chemical properties, $\mathrm{mg} \mathrm{L}^{-1}$ & \\
\hline Calcium, $\mathrm{Ca}^{2+}$ & 1.33 & 1.02 \\
Potassium, $\mathrm{K}^{+}$ & 0.51 & 0.22 \\
\hline Sodium, $\mathrm{Na}^{+}$ & 2.52 & 2.44 \\
Magnesium, $\mathrm{Mg}^{2+}$ & 0.72 & 0.53 \\
Carbonate, $\mathrm{CO}_{3}{ }^{2-}$ & 0.15 & $<0.01$ \\
Bicarbonate, $\mathrm{HCO}_{3}^{-}$ & 0.40 & 0.10 \\
Chloride, $\mathrm{Cl}^{-}$ & 3.19 & 2.74 \\
Sulfate, $\mathrm{SO}_{4}{ }^{2-}$ & 1.47 & 1.30 \\
\hline $\left.\mathrm{NN}_{\mathrm{N}} / \mathrm{m}^{3} \mathrm{NH}_{4}{ }^{+}+\mathrm{NO}_{3}{ }^{-}\right)$ & 4.78 & $<0.01$ \\
Copper, $\mathrm{Cu}^{++}$ & 10.1 & 0.22 \\
$\mathrm{Ni}^{++}$ & 0.04 & 0.02 \\
$\mathrm{Zn}^{++}$ & 0.01 & 0.01 \\
Nitrogen & 1.12 & 1.01 \\
Magnesium, $\mathrm{Mg}^{2+}$ & 0.72 & 0.53 \\
\hline
\end{tabular}

E.C: electrical conductivity. All soil and water analyses were conducted in the laboratories of the National Research Center in Egypt.

\subsection{Treatments and Experimental Design}

The experimental design included eight treatments: two different types of IW and four fertigation rates with three replicates. The two types of water used were fresh irrigation water (IW) and drainage water from fish farms (DWFF). These water types were crossed with four nitrogen application rates: $100 \%, 80 \%, 60 \%$, and $40 \%$. For the $100 \%$ chemical $\mathrm{N}$-fertilizer treatment, $\mathrm{N}$ was applied at the rate of $156 \mathrm{~kg} \mathrm{~N} \mathrm{ha}^{-1}$ per season (Table 5) in ammonium nitrate form $(33.5 \% \mathrm{~N})$. We used 24 experimental plots, each with an area of $720 \mathrm{~m}^{2}$. The statistical design was a split design for this experiment. Soil moisture probe access tubes were placed in each pilot plot to measure the moisture content of the soil (Figure 2). Table 3 shows that DWFF was richerthan IW in the major elements phosphorous, nitrogen, and potassium, which are essential nutrients for plants. It was also distinguished by micronutrients, such as nickel, zinc, and copper. In addition, it contained more microorganisms and 
OM (Table 4). The sprinkler irrigation system with fish farm wastewater did not include a filtering unit to ensure that all the beneficial biological organic materials and algae were added to the sandy soil to improve the fertility of these poor sandy soils. The planting and harvesting dates for barley were the 20th of November and 14th of April for seasons 2017/2018 and 2018/2019, respectively. The growth period for barley was 146 days, with 20 days for the initial stage, 32 days for the development stage, 57 days for the middle stage, and 37 days for the late stage.

The type of fish used was tilapia (Oreochromis niloticus) and the specific variety is tilapia niloticus (Nile tilapia), raised in 12 ponds, and the dimensionsof the pondswere $5 \times 5 \times 2 \mathrm{~m}$, meaning that the volume of the ponds was 50 cubic meters, and the density of fish was 50 fish per cubic meter, meaning that the number of fish in one pond was 2500 fish, and the total number of fish in the experiment was 30,000 fish.

Table 4. Bio-component characteristics of the drainage water from fish farms and fresh irrigation water.

\begin{tabular}{|c|c|c|}
\hline Parameter & $\begin{array}{c}\text { Drainage Water Fish Farm } \\
\text { (DWFF) }\end{array}$ & Irrigation Canal Water (IW) \\
\hline \multicolumn{3}{|c|}{ Biological properties, counts as CFU (colony forming units), $\mathrm{mL}^{-1}$} \\
\hline Total bacteria & $1.6 \times 10^{4}$ & $0.24 \times 10^{4}$ \\
\hline Total fecal coliforms & $3.2 \times 10^{3}$ & $1.9 \times 10^{3}$ \\
\hline Total fungi & 515 & 94 \\
\hline \multirow{2}{*}{$\begin{array}{c}\text { Total free } \mathrm{N}_{2} \text { fixers } \\
\text { Green algae }\end{array}$} & 606 & 55 \\
\hline & 409 & \\
\hline \multirow[t]{2}{*}{ Chlorella sp. } & & 87 \\
\hline & 122 & \\
\hline \multirow[t]{2}{*}{ Pediastrum sp. } & & 17 \\
\hline & 153 & \\
\hline Scenedesmus sp. & & 12 \\
\hline \multicolumn{3}{|l|}{ Cyanobacteria } \\
\hline & 58 & \\
\hline \multirow[t]{2}{*}{ Nostoc sp. } & & $<1$ \\
\hline & 108 & \\
\hline Oscillatoria sp. & & 14 \\
\hline
\end{tabular}


Table 5. Total amount of applied irrigation water and nitrogen for each treatment in the two studied seasons.

\begin{tabular}{|c|c|c|c|c|c|c|c|c|}
\hline \multirow{2}{*}{ Treatment } & \multirow{2}{*}{$\begin{array}{l}\text { Total Amount of Water } \\
\text { Applied }\left(\mathrm{m}^{3} \mathrm{ha}^{-1}\right)\end{array}$} & \multicolumn{3}{|c|}{ Applied Nitrogen, kgN ha ${ }^{-1},(2017 / 2018)$} & \multirow{2}{*}{$\begin{array}{c}\text { Total Amount of } \\
\text { Water Applied } \\
\left(\mathrm{m}^{3} \mathrm{ha}^{-1}\right)\end{array}$} & \multicolumn{3}{|c|}{ Applied Nitrogen, $\mathrm{kgN} \mathrm{ha}^{-1}(2018 / 2019)$} \\
\hline & & Biological & Chemical & Total & & Biological & Chemical & Total \\
\hline DWFF $100 \% \mathrm{~N}$ & 2680 & 12.81 & 156 & 168.81 & 2600 & 12.43 & 156 & 168.43 \\
\hline DWFF, $80 \% \mathrm{~N}$ & 2680 & 12.81 & 124.8 & 137.61 & 2600 & 12.43 & 124.8 & 137.23 \\
\hline DWFF, $60 \% \mathrm{~N}$ & 2680 & 12.81 & 93.6 & 106.41 & 2600 & 12.43 & 93.6 & 106.03 \\
\hline DWFF, $40 \% \mathrm{~N}$ & 2680 & 12.81 & 62.4 & 75.21 & 2600 & 12.43 & 62.4 & 74.83 \\
\hline IW, $100 \% \mathrm{~N}$ & 2680 & 0 & 156 & 156 & 2600 & 0 & 156 & 156 \\
\hline IW, $80 \% \mathrm{~N}$ & 2680 & 0 & 124.8 & 124.8 & 2600 & 0 & 124.8 & 124.8 \\
\hline IW, $60 \% \mathrm{~N}$ & 2680 & 0 & 93.6 & 93.6 & 2600 & 0 & 93.6 & 93.6 \\
\hline IW, $40 \% \mathrm{~N}$ & 2680 & 0 & 62.4 & 62.4 & 2600 & 0 & 62.4 & 62.4 \\
\hline
\end{tabular}

IW: fresh irrigation water; DWFF: drainage water of fish farms, N: Nitrogen. 


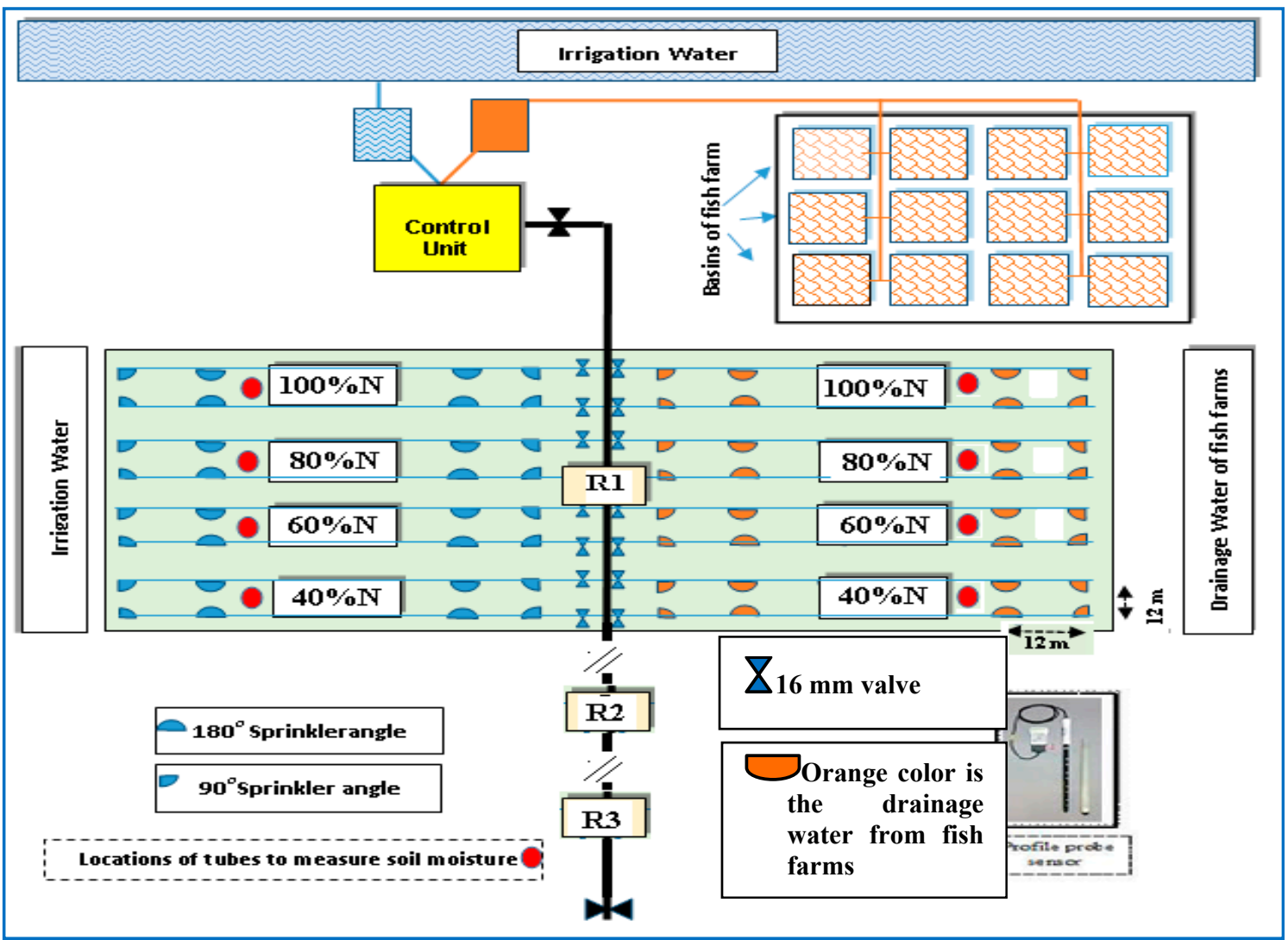

Figure 2. Layout of experimental design.

\subsection{Irrigation Requirements for Barley}

The water applied using sprinkler irrigation, which was obtained from Equation (1), was $2680 \mathrm{~m}^{3} / \mathrm{ha}$ for the $2017 / 2018$ season and $2600 \mathrm{~m}^{3}$ /ha for the $2018 / 2019$ season after deducting the amount of rainwater that fell during the two growing seasons for barley, Hordeum vulgare, variety Giza 123, where it was $681 \mathrm{~m}^{3} \mathrm{ha}^{-1}$ and was $617 \mathrm{~m}^{3} \mathrm{ha}^{-1}$ for the first and second season, respectively.

$$
\mathrm{IRg}=\left[\mathrm{ET}_{\mathrm{O}} \times \mathrm{Kc}\right] / \mathrm{I}_{\mathrm{E}}-\mathrm{R}+\mathrm{LR}
$$

where IRg is the gross irrigation requirements in $\mathrm{mm} / \mathrm{day}, \mathrm{ET}_{\mathrm{O}}$ is the reference evapotranspiration in $\mathrm{mm}$ /day (estimated by the Central Laboratory for Climate, Agricultural Research Center, Egyptian Ministry of Agriculture at El-Nubaryia farm, following the Penman-Monteith equation), Kc is crop factor [38], $\mathrm{I}_{\mathrm{E}}$ is irrigation efficiency in $\%, \mathrm{R}$ israinfall in $\mathrm{mm}$, and LRis the amount of water required for the leaching of salts in $\mathrm{mm}$.

\subsection{Evaluation Parameters}

\subsubsection{Observed and Simulated Soil Moisture Content}

Thesoil moisture content was determined using aprofile probe at a depth of $0-30 \mathrm{~cm}$ and soil moisture was also simulated.

\subsubsection{Observed and Simulated Water Application Efficiency}

Water application efficiency $\left(\mathrm{WA}_{\mathrm{E}}\right)$ is the proportion of waterstored in the root zone of the water applied in the field. The $\mathrm{WA}_{\mathrm{E}}$ was calculated using Equation (2):

$$
\mathrm{WA}_{\mathrm{E}}=\mathrm{Ds} / \mathrm{Da}
$$


where $\mathrm{WA}_{\mathrm{E}}$ is the water application efficiency $(\%)$, and Ds is the depth of stored water in the root zone (cm), calculated using Equation (3)

$$
\text { Ds }=(\theta 1-\theta 2) \times d \times \rho
$$

where $\mathrm{Da}$ is the depth of applied water $(\mathrm{mm}), \mathrm{d}$ is the soil layer depth $(\mathrm{mm}), \theta 1$ is the average of soil moisture content after irrigation $(\mathrm{g} / \mathrm{g})$ in the root zone, $\theta 2$ is the average soil moisture content before irrigation $(\mathrm{g} / \mathrm{g})$ in the root zone and $\rho$ is the bulk density of soil $\left(\mathrm{g} / \mathrm{cm}^{3}\right)$, while the simulated $\mathrm{WA}_{\mathrm{E}}$ was calculated using Equation (2) for soil moisture content variables, Ds and Da, before and after irrigation at different soil depths.

\subsubsection{Observed and Simulated Dry Matter and Grain Yield of Barley}

The dry matter and grain yield of barley was measured at harvesting time, and random samples for a sample area of $1 \mathrm{~m}^{2} \mathrm{~cm}$ were examined from each plot to estimate dry matter and grain yields in $\mathrm{kg} / \mathrm{ha}$ for the entire area of the experimental unit, which was then converted to yield per tonper ha. The simulated dry matter and grain yield of barley was measured using the different variables that are calculated and saved as output variables for dry matter and yield at harvesting time. Notably, dry matter was estimated every 15 days from the beginning of planting until harvest.

\subsubsection{Observed and Simulated Water Productivityof Barley}

The water productivity of barley was estimated following James (1988):

$$
\mathrm{WP}_{\text {barley }}=\mathrm{Ey} / \mathrm{Ir}
$$

where $\mathrm{WP}_{\text {barley }}$ is the water productivity of barley $\left(\mathrm{kg}\right.$ barley $/ \mathrm{m}^{3}$ water $)$, Ey is the primary yield $(\mathrm{kg} / \mathrm{ha})$. Ir is the applied amount of the IW $\left(\mathrm{m}^{3}\right.$ waterha ${ }^{-1}$ per season). The water productivity of barley was also simulated using Equation (4) for different yields and levels of irrigation.

$$
\text { Simulated } \mathrm{WP}_{\text {barley }}=\text { Simulated Ey/Ir }
$$

\subsubsection{SALTMED Model}

The SALTMED model [25] is freely downloadable from the Water4Crops EU funded project web site: http://www.water4crops.org/saltmed-2015-integrated-management-tool-water-crop-soil$\mathrm{n}$-fertilizers/ and from the International Commission on Irrigation and Drainage, ICID, web site: http://www.icid.org/res_tools.html\#saltmed_2015. During model calibration, the relevant SALTMED model parameters were fine-tuned against the observed data for soil moisture, dry matter, and crop yield. For calibration, IW $+100 \% \mathrm{~N}$ was selected. Various soil parameters, such as the hydraulic properties of sandy soils, were adjusted until a very close match was achieved between the actual and simulated soil moisture values. The parameters of the cultivated crop under study were also adjusted (Table 6). After a good fit for sandy soil moisture was achieved, only precise and specific control of the photosynthetic efficiency of barley dry matter and the actual yield of the crop were needed. The quality of the appropriate evaluation criteria used were the coefficient of determination $\left(R^{2}\right)$, root mean square error (RMSE), and residual mass factor (CRM). The RMSE, $R^{2}$ and CRM valueswerecalculated using Equations (6)-(8) respectively.

$$
R M S E=\sqrt{\frac{\sum\left(y_{0}-y_{s}\right)^{2}}{N}}
$$

where $y_{0}=$ predicted value, $y_{s}=$ observed value, and $N=$ total number of observations. 
Table 6. The primaryinput parameters for barley for calibrating IW, 100\%N (2017/2018), Egypt.

\begin{tabular}{|c|c|c|}
\hline Barley & Growth Stage & Parameter \\
\hline $\begin{array}{l}20 \text { November } \\
146\end{array}$ & Initial & $\begin{array}{l}\text { The sowing date of barley plant } \\
\text { Number of days to harvest }\end{array}$ \\
\hline $\begin{array}{l}20 \\
32 \\
57 \\
37\end{array}$ & $\begin{array}{l}\text { Development } \\
\text { Middle } \\
\text { Late }\end{array}$ & Age stages of barley plants \\
\hline $\begin{array}{l}0.32 \\
1.15 \\
0.27\end{array}$ & $\begin{array}{l}\text { Initial } \\
\text { Middle } \\
\text { End }\end{array}$ & Crop coefficient, Kc \\
\hline $\begin{array}{c}0.68 \\
3.5 \\
3.12\end{array}$ & $\begin{array}{l}\text { Initial } \\
\text { Middle } \\
\text { End }\end{array}$ & Leaf area index, LAI \\
\hline $\begin{array}{c}0 \\
0.5 \\
3.9\end{array}$ & & $\begin{array}{c}\text { Mini. root depth, } \mathrm{m} \\
\text { Maxi. root depth, } \mathrm{m} \\
\text { Un-stressed crop yield, } \mathrm{th}^{-1}\end{array}$ \\
\hline $\begin{array}{c}0.85 \\
0.45 \\
0.7\end{array}$ & $\begin{array}{l}\text { Initial } \\
\text { Middle } \\
\text { End }\end{array}$ & Water uptake threshold \\
\hline $\begin{array}{c}0.32 \\
0.15 \\
0.26 \\
0.04 \\
0.3 \\
0 \\
0.22 \\
11 \\
52\end{array}$ & & $\begin{array}{c}\text { Harvest index } \\
\text { Field capacity, } \mathrm{m}^{3} \mathrm{~m}^{-3} \\
\text { Saturated soil moisture content, } \mathrm{m}^{3} \mathrm{~m}^{-3} \\
\text { Wilting point, } \mathrm{m}^{3} \mathrm{~m}^{-3} \\
\text { Root width factor } \\
\text { Residual water content, } \mathrm{m}^{3} \mathrm{~m}^{-3} \\
\text { Lambda pore size } \\
\text { Bubbling pressure, } \mathrm{cm} \\
\text { Max. depth for evaporation, } \mathrm{mm}\end{array}$ \\
\hline
\end{tabular}

The $\mathrm{R}^{2}$ statistics demonstrate the ratio between the scatter of simulated values to the average value of measurements:

$$
R^{2}=\left\{\frac{1}{N} \frac{\sum\left(y_{o}-y_{o}^{-}\right)\left(y_{s}-y_{s}^{-}\right)}{\sigma y_{o}-\sigma y_{s}}\right\}
$$

where $y_{o}^{-}=$averaged observed value, $y_{s}^{-}=$averaged simulated value, $\sigma y_{0}=$ observed data standard deviation, and $\sigma y_{s}=$ simulated data standard deviation.

The coefficient of residual mass (CRM) is defined in Equation (8):

$$
\mathrm{CRM}=\frac{\left(\sum \mathrm{y}_{\mathrm{o}}-\sum \mathrm{y}_{\mathrm{s}}\right)}{\sum \mathrm{y}_{\mathrm{o}}}
$$

Whenever these evaluation criteria are related to the following values, this indicates the high ability of this model to simulate the actual values. As for the full compatibility between the observed data and the simulation, the RMSE, CRM, and $R^{2}$ values should be equal to $0.0,0.0$, and 1.0 , respectively.

\subsection{Statistical Analysis}

Most of the data were subjected to statistical analysis to clarify the discrepancy between the different treatments under study as described by Snedecor and Cochran [39]. A joint statistical analysis of the results for both seasons was conducted following the method adopted by Steel and Torrie [40], where the average values of the recorded data are compared using least significant differences (L.S.D with significance at $<0.05$ ). 


\section{Results and Discussion}

\subsection{Soil Moisture Content}

Figure 3 shows the effect of water quality and nitrogen fertigation rate on the soil moisture content (SMC) of the barley root zone before irrigation under the maximum water requirements of the barley crop during the first growing season (2017/2018). The results for the second season (2018/2019) are not included in the figure, as they show similar outcomes.

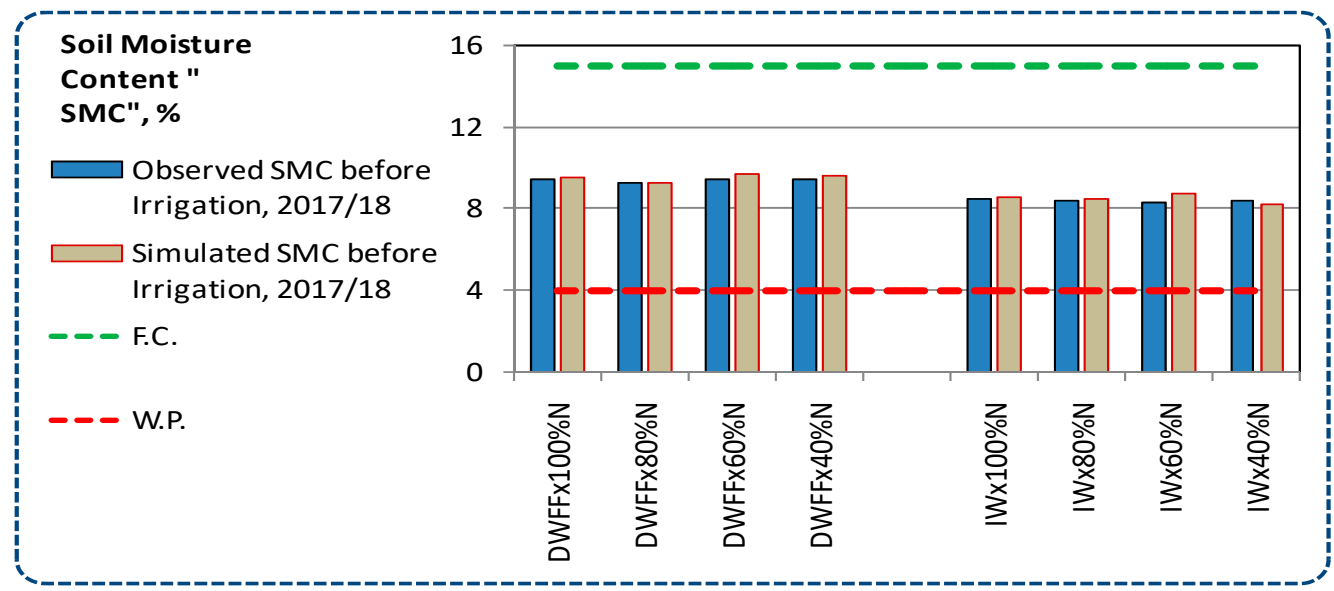

Figure 3. Effect of water quality and fertigation rate of nitrogen on the soil moisture content before irrigation at peak during the 2017/2018 growing season compared with the simulated soil moisture content for all treatments: drainage water from fish farms (DWFF), fresh irrigation water (IW) and nitrogen $(\mathrm{N})$.

When measuring the SMC under all the transactions under study, it was observed that they did not differ under the treatments that were irrigated with IW while the values were slightly higher under the transactions that irrigated using DWFF, and this may be due to the the OM added with the DWFF keeping the water in the root zone in the sandy soil.

SMC did not change significantly with an increase in nitrogen fertigation rates. Perhaps this was due to the amount of water added being the same for all treatments for the same growing season.

Initially, the SMC was calibrated with IW $+100 \% \mathrm{~N}$ and validated against the other treatments for seasons 2017/2018 and 2018/2019. The model calibration simulated the SMC at a depth of 0-30 cm (Figure 4) for the studied soil for the 2017/2018 season, and the SMC was validated for the 2018/2019 season. The overall validation treatments for the SMC of the IW and DWFF treatments are shown here. The other treatments received the same amount of IW and showed very similar results (Figures 5 and 6). Overall, there was a close fit between the data simulated by the SALTMED model and the observed data during the calibration and validation processes. These results are similar to those obtained by $[25,27,35-37,41,42]$.

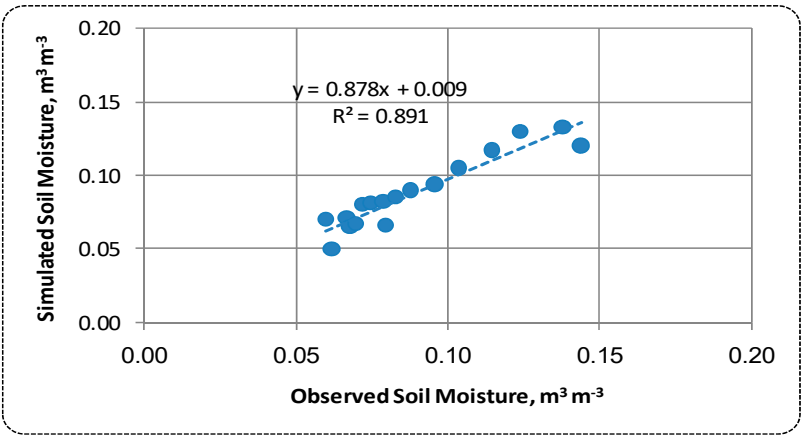

Figure 4. Soil moisture calibration for fresh irrigation water and 100\%N during the $2017 / 2018$ season. 


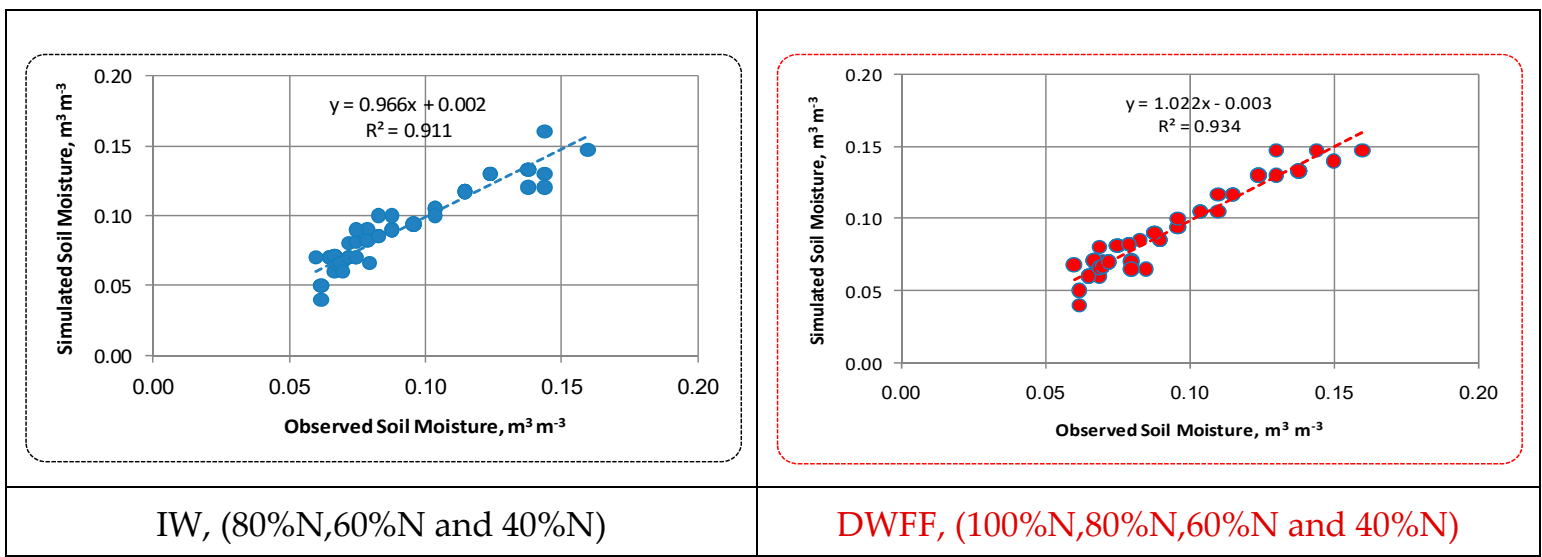

Figure 5. Observed and simulated soil moisture at a depth of 0-30 cm, during the 2017/2018 season, for overall validation treatments: drainage water from fish farms (DWFF), fresh irrigation water (IW) and Nitrogen $(\mathrm{N})$.

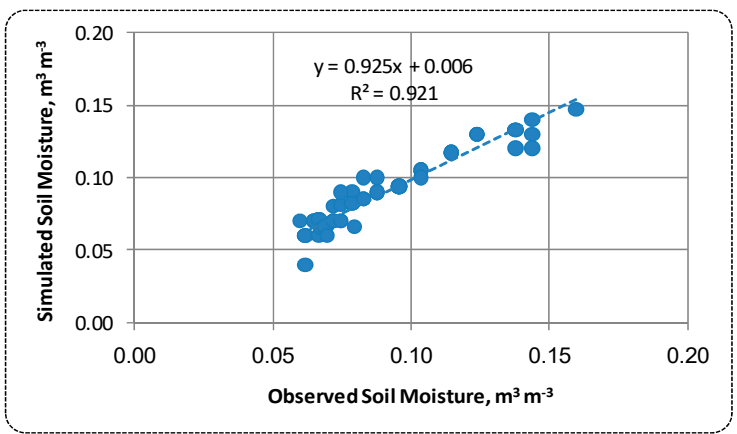

IW $(80 \% \mathrm{~N}, 60 \% \mathrm{~N}$ and $40 \% \mathrm{~N})$

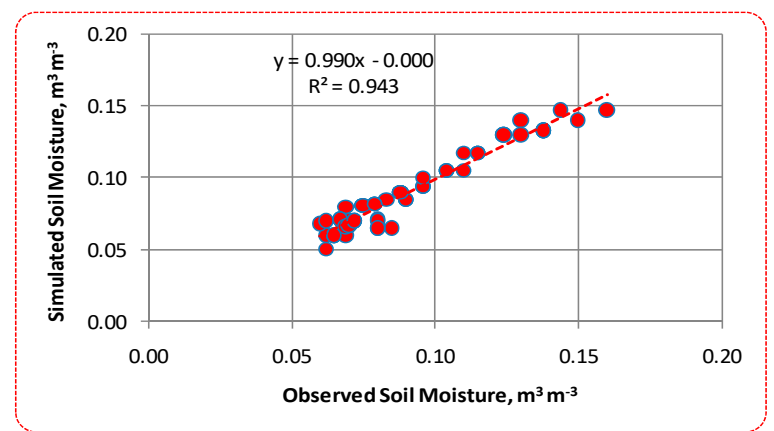

DWFF $(100 \% \mathrm{~N}, 80 \% \mathrm{~N}, 60 \% \mathrm{~N}$ and $40 \% \mathrm{~N})$

Figure 6. Observed and simulated soil moisture at a depth of 0-30 cm depth, during the 2018/2019 season, for overall validation treatments: drainage water of fish farms (DWFF), fresh irrigation water (IW), and Nitrogen (N).

The SALTMED model demonstrated extremely high performance and sensitivity to simulate the SMC changes resulting from irrigation operations (Table 7), where the value of $\mathrm{R}^{2}$ ranged from 0.89 to 0.94 . The simulated and observed sandy soil moisture values for all treatments combined showed a significant and high correlation for the 2017/2018 and 2018/2019 growing seasons.

Table 7. Coefficient of determination $\left(\mathrm{R}^{2}\right)$, root mean square error (RMSE), and residual mass factor $(\mathrm{CRM})$ coefficients for soil moisture in one layer depth $(0-30 \mathrm{~cm})$ for all irrigation treatments.

\begin{tabular}{|c|c|c|c|c|c|c|c|c|c|}
\hline \multirow{2}{*}{ Date } & \multirow{2}{*}{$\begin{array}{l}\text { Correlation } \\
\text { Parameter }\end{array}$} & \multicolumn{4}{|c|}{ Drainage Water of Fish Farms } & \multicolumn{4}{|c|}{ Irrigation Water } \\
\hline & & $100 \% \mathrm{~N}$ & $80 \% \mathrm{~N}$ & $60 \% \mathrm{~N}$ & $40 \% \mathrm{~N}$ & $100 \% \mathrm{~N}$ & $80 \% \mathrm{~N}$ & $60 \% \mathrm{~N}$ & $40 \% \mathrm{~N}$ \\
\hline \multirow{3}{*}{$2017 / 2018$} & $\mathrm{R}^{2}$ & 0.89 & & 0.91 & & \multicolumn{4}{|c|}{0.93} \\
\hline & RMSE & \multicolumn{4}{|c|}{-0.012} & \multicolumn{4}{|c|}{0.005} \\
\hline & $\mathrm{RCM}$ & \multicolumn{4}{|c|}{-0.017} & \multicolumn{4}{|c|}{-0.036} \\
\hline \multirow{3}{*}{$2018 / 2019$} & $\mathrm{R}^{2}$ & \multicolumn{4}{|c|}{0.92} & \multicolumn{4}{|c|}{0.94} \\
\hline & RMSE & \multicolumn{4}{|c|}{0.009} & \multicolumn{4}{|c|}{0.007} \\
\hline & $\mathrm{RCM}$ & \multicolumn{4}{|c|}{-0.015} & \multicolumn{4}{|c|}{-0.023} \\
\hline
\end{tabular}




\subsection{Water Application Efficiency}

For the two studied seasons, $\mathrm{WA}_{\mathrm{E}}$ was investigated using different water qualities for irrigation and different rates of nitrogen fertilizer under sandy soil conditions.

$W_{E}$ increased under irrigation with DWFF in comparison to IW (Figure 7). This is likely due to the increase in the OM that was added as a result of irrigating with DWFF and the OM playing a vital role in increasing the water holding capacity and preventing nutrients leaching from the soil.

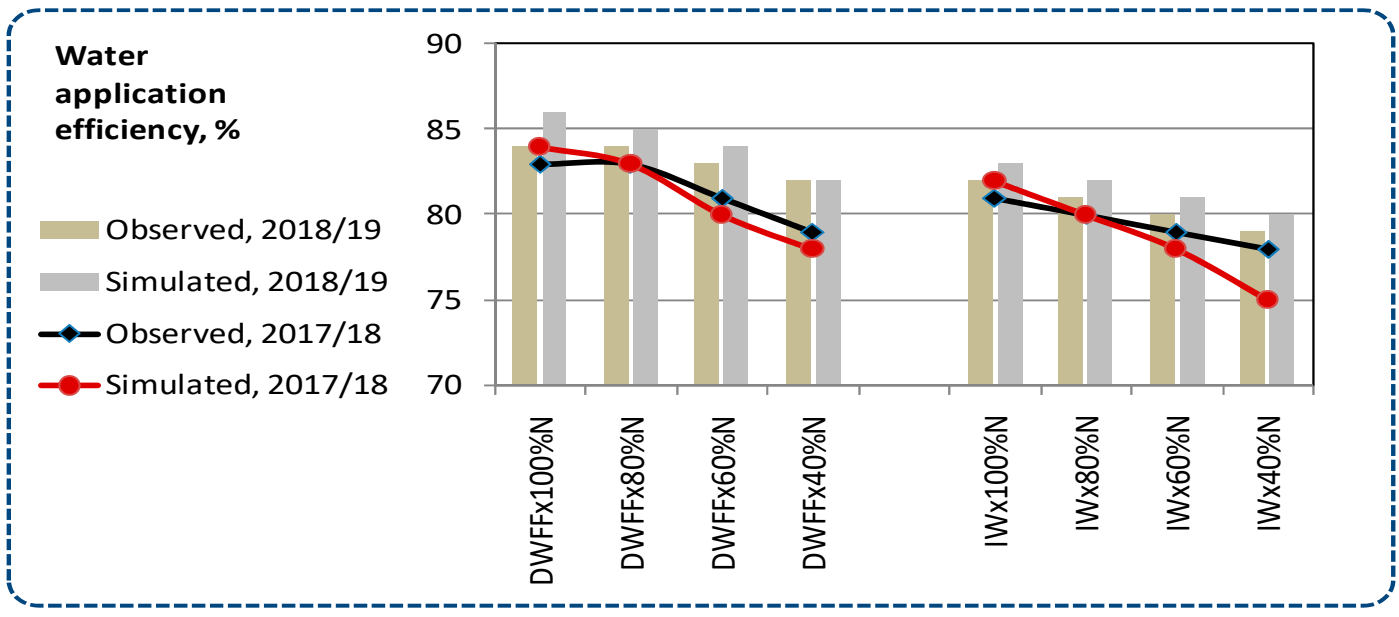

Figure 7. Effect of water quality and fertigation rate of nitrogen on the water application efficiency $\left(\mathrm{WA}_{\mathrm{E}}\right)$ at the peak of irrigation during growing seasons and compared with simulated WA $\mathrm{A}_{\mathrm{E}}$ for all treatments for the 2017/2018 and 2018/2019 growing seasons for different treatments: drainage water from fish farms (DWFF), fresh irrigation water (IW), and nitrogen (N).

The effect of the fertigation rate of nitrogen on the $\mathrm{WA}_{\mathrm{E}}$ is shown in Figure 7. $\mathrm{WA}_{\mathrm{E}}$ decreased with a decreasing fertigation rate, which could be due to the increasein the fertigation rate increasing the size of the plants roots, enabling the absorbtion of most of the added IW and fertilizers.

There was a positive correlation between the simulated and observed values for both the 2017/2018 and $2018 / 2019$ seasons (Figures 7 and 8 ), where the $R^{2}$ was 0.89 , indicating the accuracy of the SALTMED model for simulating $\mathrm{WA}_{\mathrm{E}}$.

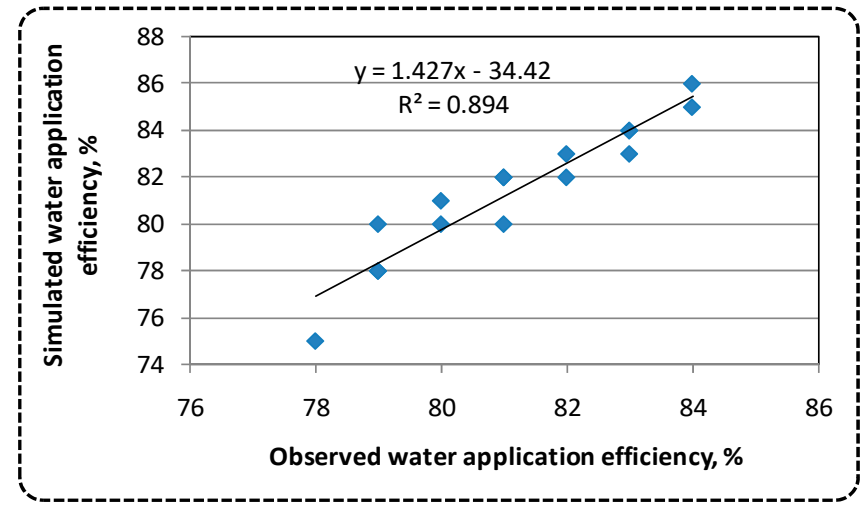

Figure 8. Observed versus simulated water application efficiency for all treatments for bothseasons.

\subsection{Nitrogen Concentration in the Soil Layer of the Effective Root Zone}

Figure 9 shows that the N concentration of the soil layer (N-CSL) was affected for the $100 \% \mathrm{~N}$, $80 \% \mathrm{~N}, 60 \% \mathrm{~N}$ and $40 \% \mathrm{~N}$ treatments for both the IW and DWFF treatments. 


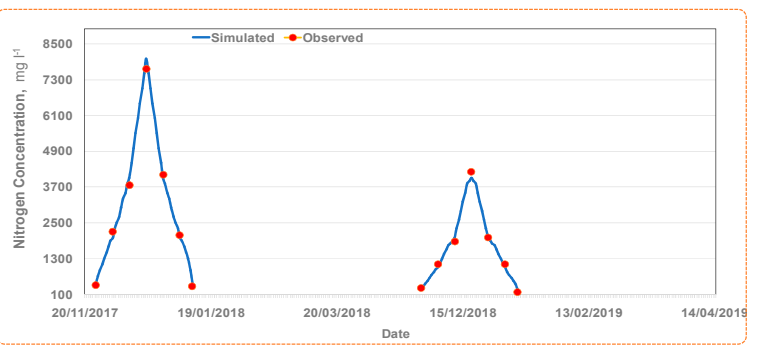

$100 \% \mathrm{~N}+\mathrm{DWFF}$

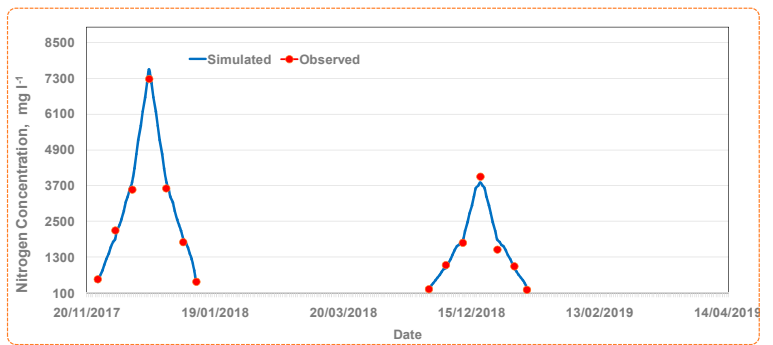

$80 \% \mathrm{~N}+\mathrm{DWFF}$

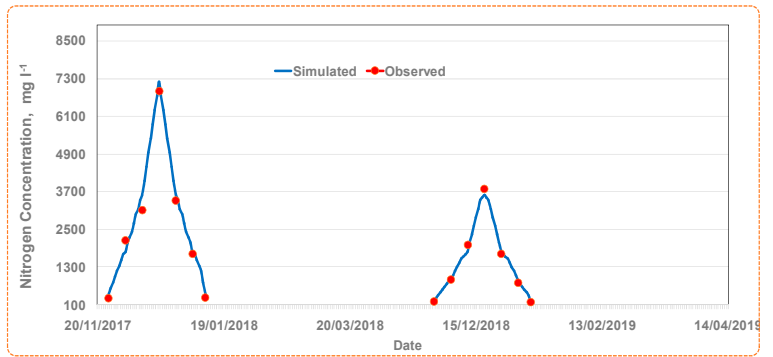

$60 \% \mathrm{~N}+\mathrm{DWFF}$

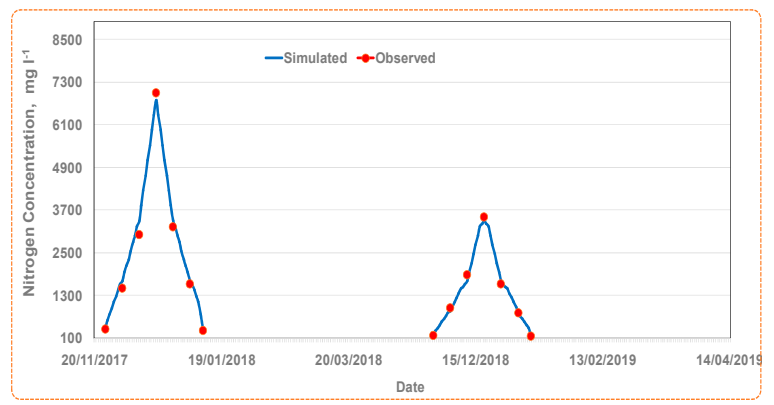

$40 \% \mathrm{~N}+\mathrm{DWFF}$

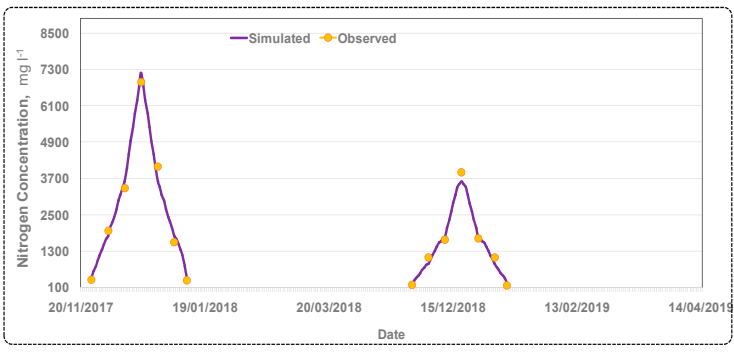

$100 \% \mathrm{~N}+\mathrm{IW}$

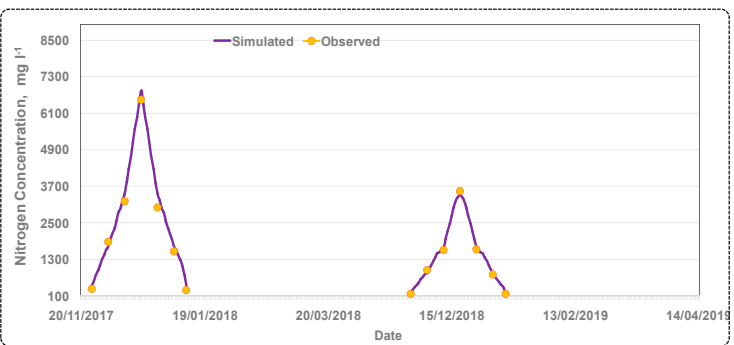

$80 \% \mathrm{~N}+\mathrm{IW}$

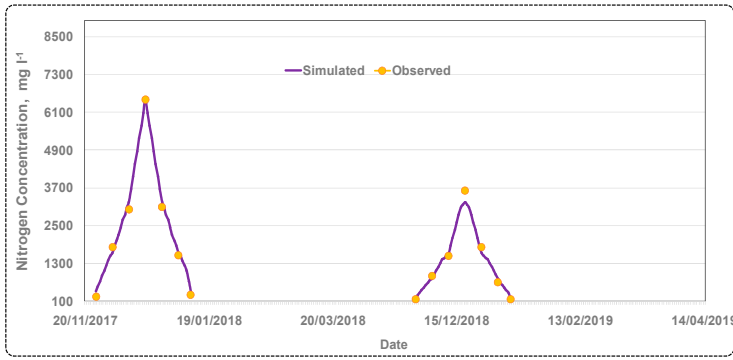

$60 \% \mathrm{~N}+\mathrm{IW}$

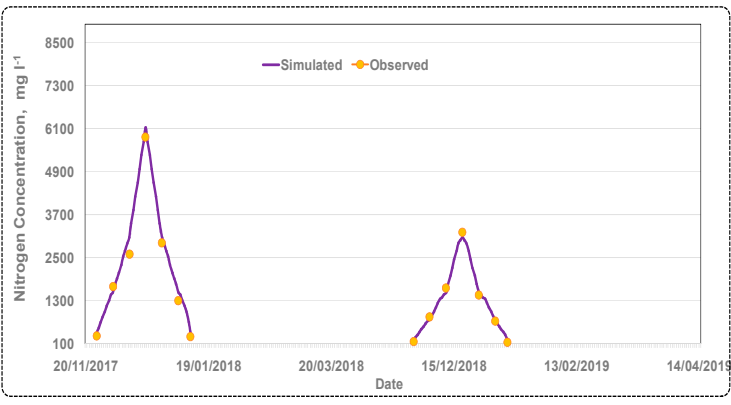

$40 \% \mathrm{~N}+\mathrm{IW}$

Figure 9. Observed and simulated nitrogen concentration of the soil layer for all treatments during the 2017/2018 and 2018/2019 seasons for different treatments: drainage water from fish farms (DWFF), fresh irrigation water (IW) and nitrogen (N).

The N-CSL values were higher in season 2017/2018 than season 2018/2019. This may be due to the increase in the amount of rain during the effective period of barley fertilization during the second growing season (2018/2019) when there was $34.48 \mathrm{~mm}$ of rain during January, which translates to $344.8 \mathrm{~m}^{3} \mathrm{ha}^{-1}$ and led to an increase in the rate of the leaching of fertilizer elements, including nitrogen, from the root zone. This led to a decrease in the N-CSL compared with the first season (2017/2018), in which the amount of rain that fell at the end of the growing season and outside of the effective 
period of fertilization did not affect the concentration of fertilizer elements during the effective period of fertilization.

There was an improvement in the N-CSL with DWFF irrigation compared with IW irrigation in both the 2017/2018 and 2018/2019 seasons. This is due to the additional amount of biological nitrogen and other nutrients already present in the DWFF.

The N-CSL increased with increasing fertigation of $\mathrm{N}$, which seems logical, as increasing the rate of $\mathrm{N}$-Fertigation increases the $\mathrm{N}$ concentration in the root zone, leading to an increase in $\mathrm{N}$.

After making a comparison between the actual $\mathrm{N}$ concentration values in the root diffusion region of the barley intakes measured using the field and simulated values given by the model (Figures 9 and 10), it was found that there was a high positive correlation between them during the 2017/2018 and 2018/2019 growing seasons, with an $R^{2}$ of 0.99 .

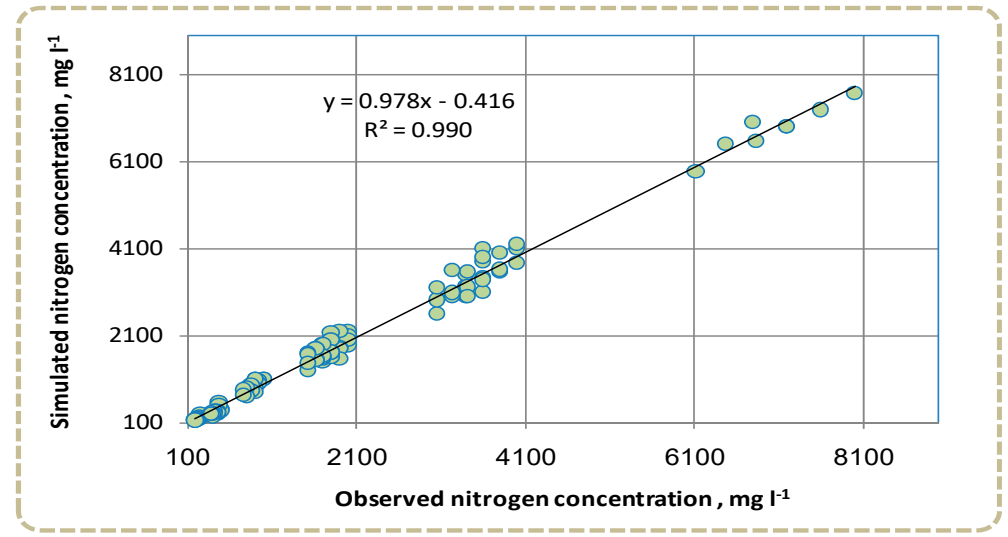

Figure 10. Observed versus simulated nitrogen concentration of the soil layer for all treatments for two seasons.

\subsection{Nitrogen Uptake}

Nitrogen up take changed for the $100 \% \mathrm{~N}, 80 \% \mathrm{~N}, 60 \% \mathrm{~N}$ and $40 \% \mathrm{~N}$ treatments for both the IW and DWFF treatments (Figure 11).

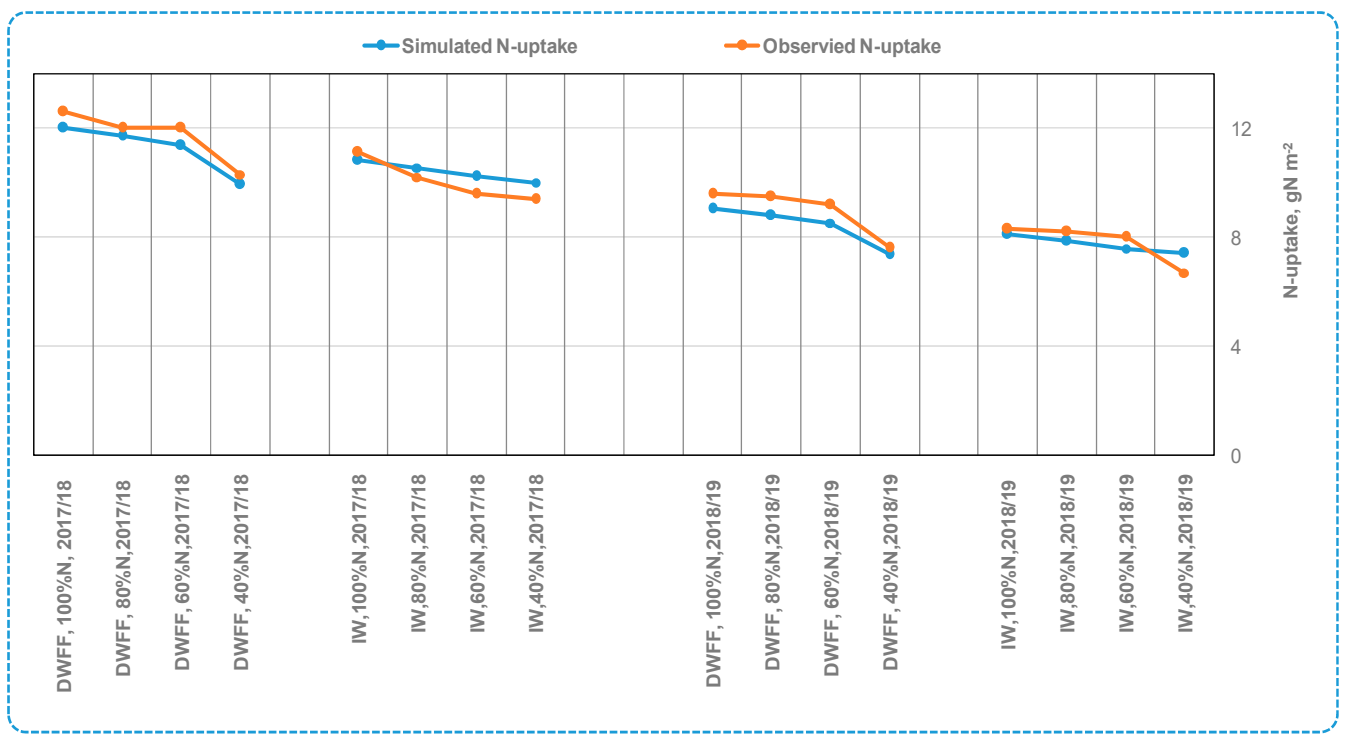

Figure 11. Effect of water quality and nitrogen fertigation on $\mathrm{N}$ uptake during growing seasons and compared with simulated nitrogen uptake for the 2017/2018 and 2018/2019 seasons for all treatments: drainage water from fish farms(DWFF), fresh irrigation water (IW) and nitrogen (N). 
The nitrogen uptake values were higher for the 2017/2018 season than the 2018/2019 season. This finding is likely due to the increase in the amount of rain water falling during the effective period of barley fertilization in the second growing season (2018/2019) when the amount of rainfall was $34.48 \mathrm{~mm}$ during January, which translates to $344.8 \mathrm{~m}^{3} \mathrm{ha}^{-1}$ and led to an increase in the rate of leaching of fertilizer elements, including $\mathrm{N}$, from the root zone, which led to a decrease in the concentration of N. Previous influences led to a negative effect on the decrease of nitrogen uptake compared with the first season (2017/2018). For the 2018/2019 season, the amount of rain that fell at the end of the growing season and outside of the effective period of fertilization did not affect the concentration of fertilizer elements during the effective period of fertilization.

Total $\mathrm{N}$ uptake improved with the use of DWFF irrigation for barley compared with when irrigation with IW was used during growing seasons. This was due to the presence of excess and additional amounts of biological $\mathrm{N}$ in addition to other nutrients that were already present in the DWFF, with the additional $\mathrm{N}$ being estimated to be $12.81 \mathrm{~kg}$ of $\mathrm{N}$ per ha in the $2017 / 2018$ season and $12.43 \mathrm{~kg}$ of $\mathrm{N}$ per ha in the 2018/2019 season compared with that for IW irrigation.

The total $\mathrm{N}$ uptake increased with an increasing fertigation rate of $\mathrm{N}$, which seems logical, as increasing $\mathrm{N}$-fertigation increases the concentration of $\mathrm{N}$ in the root zone, leading to increased nitrogen.

Figures 11-13 indicate that there was apositive correlation between the simulated and observed values of N uptake during the 2017/2018 and 2018/2019 seasons, with an $\mathrm{R}^{2}$ of 0.916 , which indicates that the SALTMED model quite accurately simulated the $\mathrm{N}$ uptake related to water quality and the fertigation rate of $\mathrm{N}$.

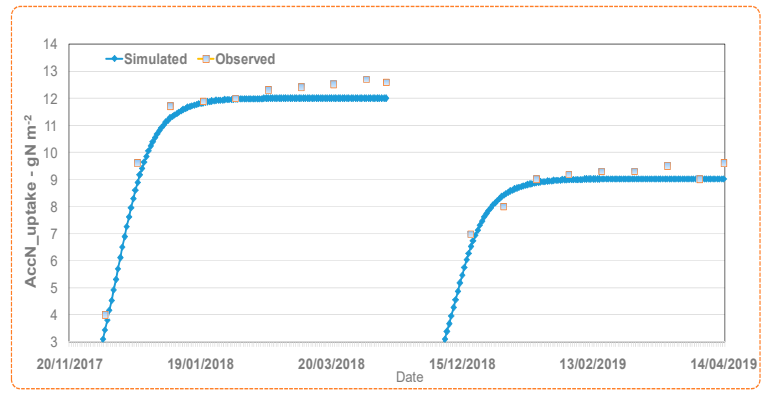

$100 \% \mathrm{~N}+\mathrm{DWFF}$

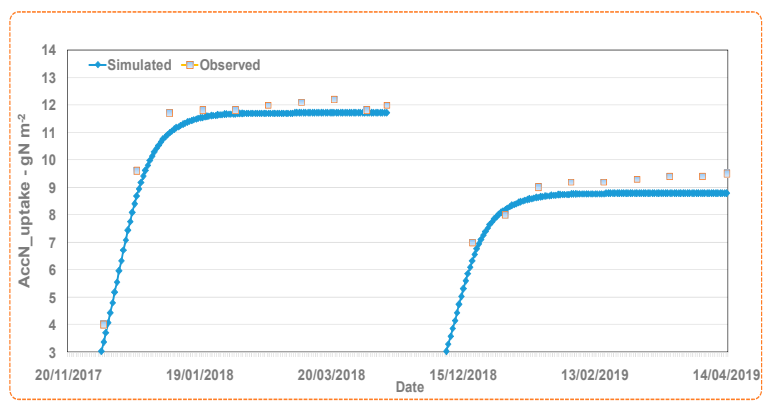

$80 \% \mathrm{~N}+\mathrm{DWFF}$

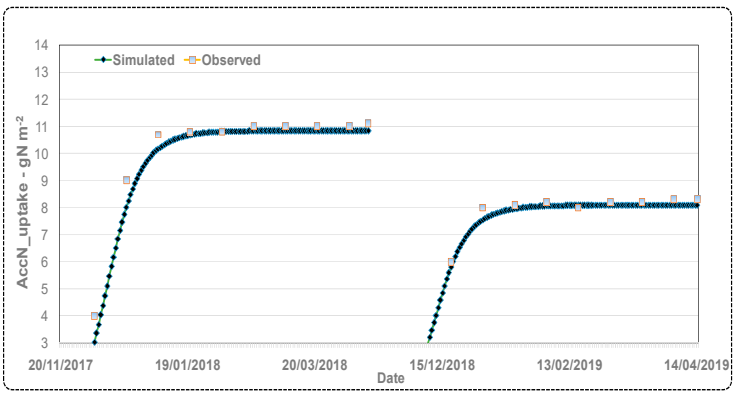

$100 \% \mathrm{~N}+\mathrm{IW}$

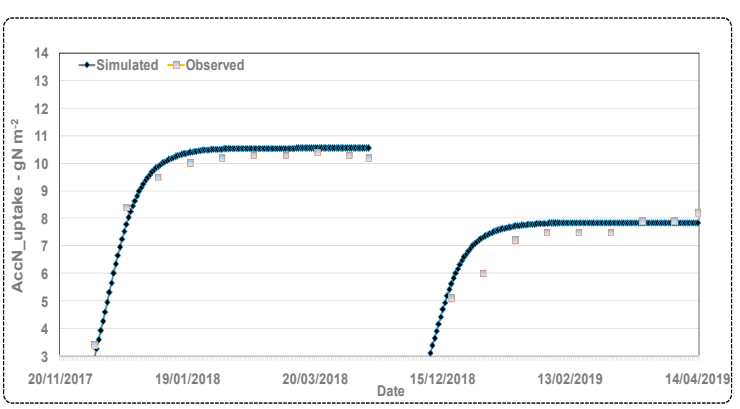

$80 \% \mathrm{~N}+\mathrm{IW}$

Figure 12. Cont. 


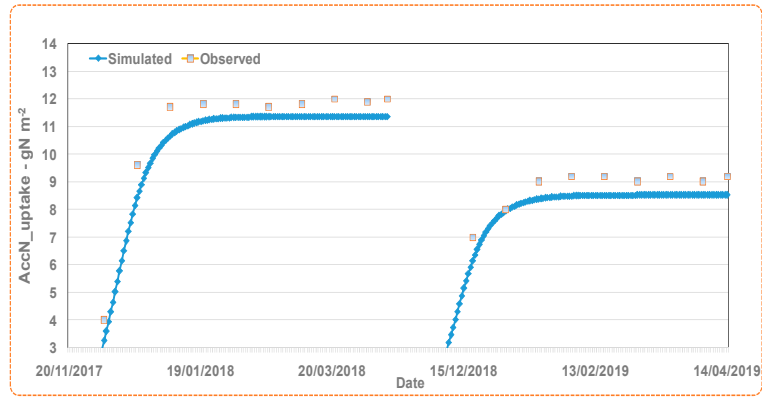

$60 \% \mathrm{~N}+\mathrm{DWFF}$

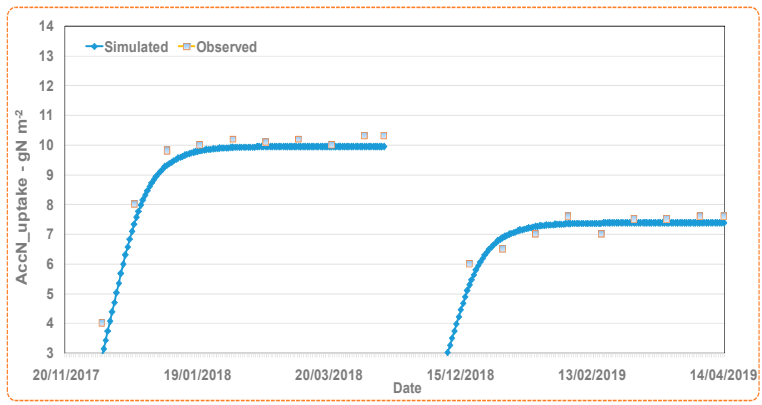

$40 \% \mathrm{~N}+\mathrm{DWFF}$

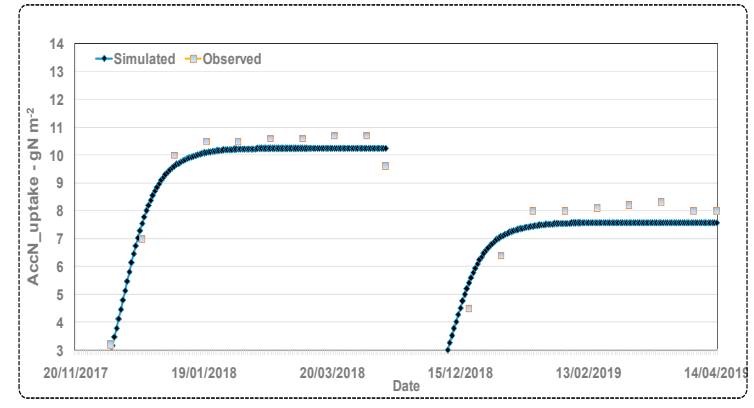

$60 \% \mathrm{~N}+\mathrm{IW}$

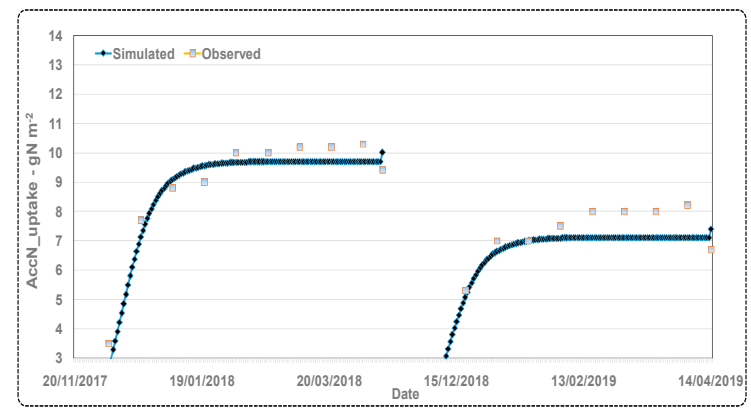

$40 \% \mathrm{~N}+\mathrm{IW}$

Figure 12. Observed and simulated accumulated-nitrogenuptake during 2017/2018 and 2018/2019 for all treatments: drainage water from fish farms(DWFF), fresh irrigation water (IW) and nitrogen (N).

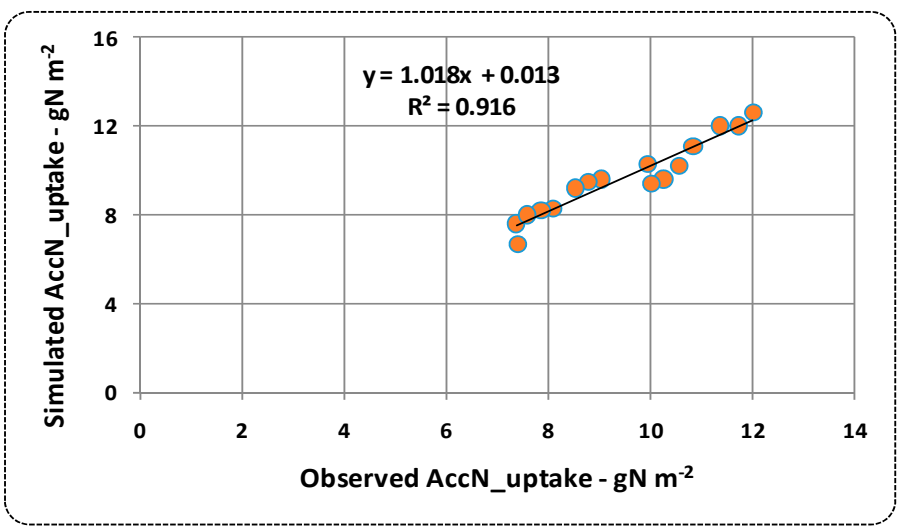

Figure 13. Observed versus simulated accumulated-nitrogen uptake for all treatments for two seasons.

\subsection{Barley Dry Matter}

Table 8 shows that the average dry matter weight of barley was affected by the $100 \% \mathrm{~N}, 80 \% \mathrm{~N}$, $60 \% \mathrm{~N}$, and $40 \% \mathrm{~N}$ treatments for both the IW and DWFF treatments. The average weight of barley dry matter was higher when irrigating with DWFF than when irrigating with IW in the 2017/2018 and 2018/2019 seasons. This is due to the increasein N uptake under DWFF, because this water had additional bio-nitrogen and other bio-nutrients. 
Table 8. Effect of water quality and nitrogen fertigation on the average weight of barley dry matter and compares it to simulated barley dry matter for all treatments.

\begin{tabular}{|c|c|c|c|c|c|c|c|}
\hline \multicolumn{2}{|c|}{ Treatments } & \multicolumn{2}{|c|}{$\begin{array}{c}\text { Observed Dry } \\
\text { Matter-2017/2018, } \\
\text { ton/ha }\end{array}$} & \multirow[t]{3}{*}{$\begin{array}{c}\text { Simulated Dry } \\
\text { Matter-2017/2018, } \\
\text { ton/ha }\end{array}$} & \multicolumn{2}{|c|}{$\begin{array}{c}\text { Observed Dry } \\
\text { Matter-2018/2019, } \\
\text { ton/ha }\end{array}$} & \multirow[t]{3}{*}{$\begin{array}{l}\text { Simulated Dry } \\
\text { Matter-2018/2019, } \\
\text { ton/ha }\end{array}$} \\
\hline \multirow{2}{*}{$\begin{array}{l}\text { Water } \\
\text { quality }\end{array}$} & DWFF & $11.9 \mathrm{a}$ & \pm 0.9 & & $12.5 \mathrm{a}$ & \pm 1.0 & \\
\hline & IW & $11.2 \mathrm{~b}$ & \pm 1.1 & & $11.5 \mathrm{~b}$ & \pm 1.2 & \\
\hline \multicolumn{2}{|c|}{ LSD at $\alpha 0.05$} & 0.3888 & & & 0.3513 & & \\
\hline \multirow{4}{*}{$\mathrm{N}$-fertigation } & $100 \% \mathrm{~N}$ & $12.5 \mathrm{a}$ & \pm 0.3 & & $13.0 \mathrm{a}$ & \pm 0.4 & \\
\hline & $80 \% \mathrm{~N}$ & $12.4 \mathrm{a}$ & \pm 0.5 & & $12.9 \mathrm{a}$ & \pm 0.6 & \\
\hline & $60 \% \mathrm{~N}$ & $11.2 \mathrm{~b}$ & \pm 0.6 & & $11.6 \mathrm{~b}$ & \pm 0.7 & \\
\hline & $40 \% \mathrm{~N}$ & $10.3 \mathrm{c}$ & \pm 0.6 & & $10.6 \mathrm{c}$ & \pm 0.7 & \\
\hline \multicolumn{2}{|c|}{ LSD at $\alpha 0.05$} & 0.4412 & & & 0.5054 & & \\
\hline \multirow{8}{*}{ Interaction } & $\begin{array}{c}\text { DWFF } \times \\
100 \% N\end{array}$ & 12.6 & \pm 0.4 & 13.1 & 13.2 & \pm 0.4 & 13.4 \\
\hline & $\begin{array}{c}\text { DWFF } \times \\
80 \% \mathrm{~N}\end{array}$ & 12.7 & \pm 0.2 & 13.0 & 13.4 & \pm 0.3 & 13.5 \\
\hline & $\begin{array}{c}\text { DWFF } \times \\
60 \% \mathrm{~N}\end{array}$ & 11.6 & \pm 0.6 & 12.2 & 12.2 & \pm 0.6 & 12.3 \\
\hline & $\begin{array}{c}\text { DWFF } \times \\
40 \% \mathrm{~N}\end{array}$ & 10.9 & \pm 0.1 & 10.1 & 11.2 & \pm 0.1 & 11.8 \\
\hline & $\begin{array}{c}\mathrm{IW} \times \\
100 \% \mathrm{~N}\end{array}$ & 12.3 & \pm 0.2 & 12.3 & 12.7 & \pm 0.2 & 11.7 \\
\hline & $\begin{array}{l}\mathrm{IW} \times \\
80 \% \mathrm{~N}\end{array}$ & 12.0 & \pm 0.3 & 12.1 & 12.4 & \pm 0.3 & 11.8 \\
\hline & $\begin{array}{l}\mathrm{IW} \times \\
60 \% \mathrm{~N}\end{array}$ & 10.8 & \pm 0.3 & 11.0 & 11.1 & \pm 0.3 & 11 \\
\hline & $\begin{array}{l}\text { IW } \times \\
40 \% \mathrm{~N}\end{array}$ & 9.8 & \pm 0.3 & 9.9 & 10.0 & \pm 0.3 & 10.1 \\
\hline \multicolumn{2}{|c|}{ LSD at $\alpha 0.05$} & N.S & & & N.S & & \\
\hline \multicolumn{2}{|c|}{ Equation, $R^{2}$} & \multicolumn{3}{|c|}{$y=1.152 x-1.642, R^{2}=0.896$} & \multicolumn{3}{|c|}{$y=0.883 x+1.331, R^{2}=0.820$} \\
\hline
\end{tabular}

$\mathrm{N}$ : Fertigation Rates of Nitrogen; IW: fresh irrigation water; DWFF: drainage water from fish farms.

The average weight of barley dry matter increased with increasing $\mathrm{N}$ uptake, which increased with increasing $\mathrm{N}$-fertigation. The observed and simulated dry matter weights showed agood fit for all age stages of barley plants for most treatments. The SALTMED model simulated the dry matter values with an $R^{2}$ of 0.896 for all treatments for $2017 / 2018$ and 0.82 for all treatments during 2018/2019 (Table 8).

\subsection{Barley Yield}

Figure 14 and Table 9 indicate the impact of N-fertigation rates with DWFF and IW irrigation on the yield of barley duringthe growing seasons of 2017/2018 and 2018/2019.

There was a strong positive effect on barley yield with increasing N-fertilization for DWFF and IW irrigation treatments in both growing seasons: 2017/2018 and 2018/2019. The barley yield under DWFF was higher than that under IW, increasing by $14.7 \%$, with a range of $5.1 \%-25.9 \%$, for the $2017 / 2018$ season and increasing by $20 \%$,with a range of $9.8 \%-33.3 \%$,for the $2018 / 2019$ season.

The biggest difference was related to the treatment with the least nitrogen. This wasdue to the excess and additional amount of dissolved bio-nitrogen in addition to the other bio-nutrients inherent in DWFF. Of note here is an additional amount of dissolved nitrogen inherent in DWFF (12.81 kg N ha ${ }^{-1}$ in $2017 / 2018$ and $12.43 \mathrm{~kg} \mathrm{~N} \mathrm{ha}^{-1}$ in 2018/2019) along with additional phosphorous and potassium. These findings are in agreement with the results of other reports showing that the integrated cultivation of rice and fish is environmentally sound and healthy, as fish farming improves soil quality and fertility by increasing the availability of nitrogen and $[43,44]$. In general, crop yields and total $\mathrm{N}$ uptake increased by increasing the rate of nitrogen fertilization. 


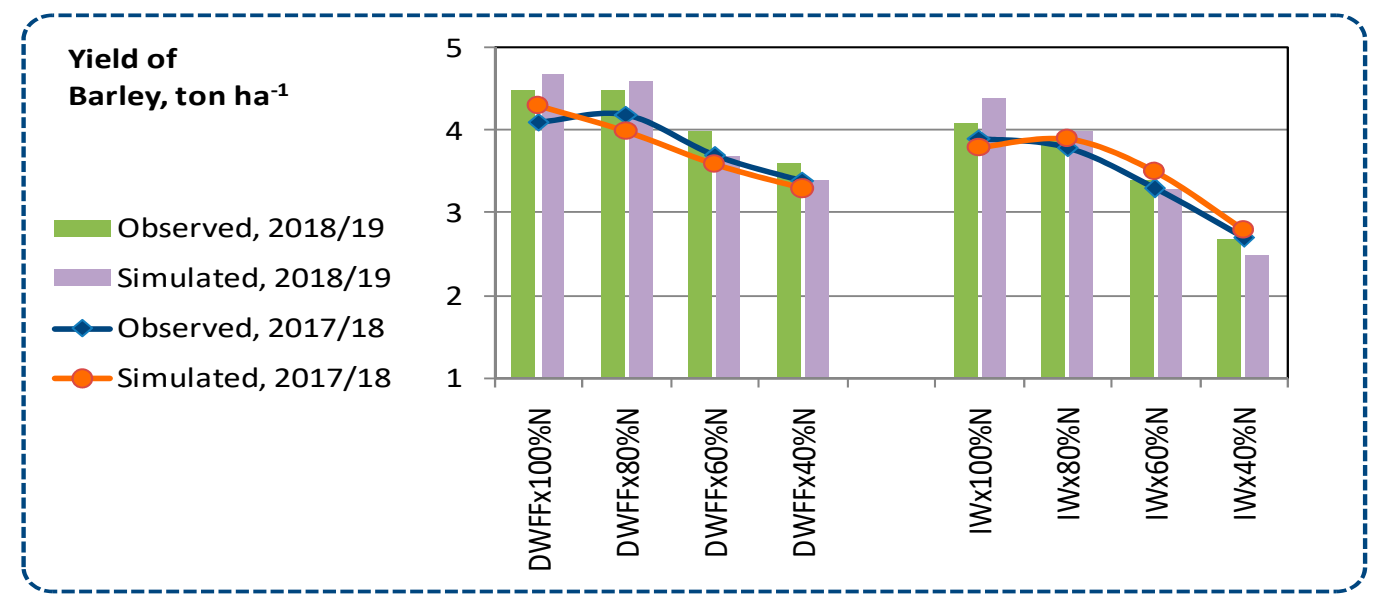

Figure 14. Effect of water quality and the fertigation rate of nitrogen on the observed and simulated yield of barley for the 2017/2018 and 2018/2019 seasons for all treatments: drainage water of fish farms(DWFF); fresh irrigation water (IW) and Nitrogen (N).

The statistical analysis indicated that there were significant differences between crop yield values under all treatments during the two seasons:2017/2018 and 2018/2019. The yield was found to decrease for specific treatments for the 2017/2018 and 2018/2019 seasons:

DWFF $+100 \% \mathrm{~N}>$ DWFF $+80 \% \mathrm{~N}>\mathrm{IW}+100 \% \mathrm{~N}>\mathrm{IW}+80 \% \mathrm{~N}>$ DWFF $+60 \% \mathrm{~N}>\mathrm{DWFF}+40 \% \mathrm{~N}$ $>\mathrm{IW}+60 \% \mathrm{~N}>\mathrm{IW}+40 \% \mathrm{~N}$. Figures 14 and 15 indicate that there is astrong correlation between the observed and simulated crop yield values for all treatments for the two growing seasons with a $\mathrm{R}^{2}$ of 0.915 for all treatments.

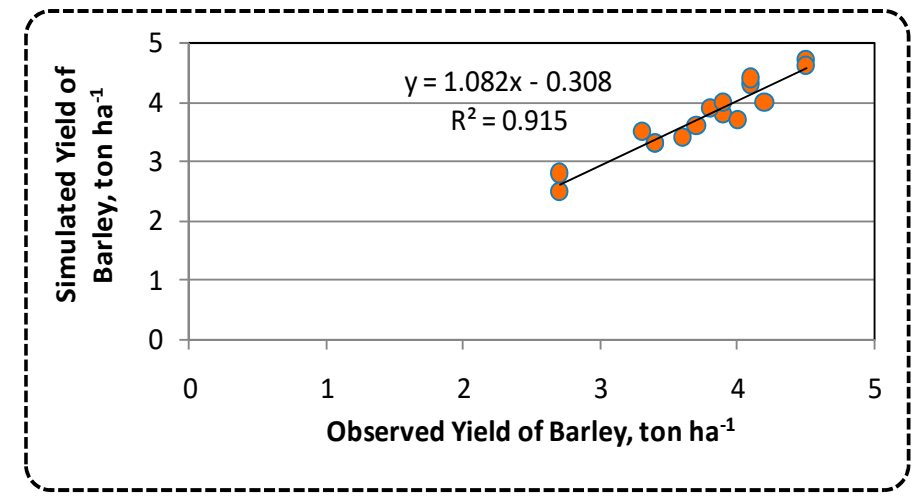

Figure 15. Observed versus simulated yield for all treatments for seasons 2017/2018 and 2018/2019.

\subsection{Water Productivity of Barley}

Water productivity of barley ( $\mathrm{WP}_{\text {barley}}$ ) was estimated as the amount of grain yield in $\mathrm{kg}$ per $\mathrm{m}^{3}$ of applied IW. Figure 16 shows the impact of $\mathrm{N}$-fertigation rates by using DWFF and IW on the $\mathrm{WP}_{\text {barley }}$ during 2017/2018 and 2018/2019. 
Table 9. Effect of the water quality and nitrogen fertigation rate on the Harvest Index, grain yield, and water productivity of barley.

\begin{tabular}{|c|c|c|c|c|c|c|c|c|c|}
\hline \multicolumn{2}{|c|}{ Treatments } & \multirow[t]{4}{*}{ H.I } & \multicolumn{2}{|c|}{ Observed Yield, tha ${ }^{-1}$} & \multirow{4}{*}{$\begin{array}{c}\text { Simulated } \\
\text { Yield, } \mathrm{t} \mathrm{ha}^{-1}\end{array}$} & \multirow{2}{*}{$\begin{array}{c}\begin{array}{c}\text { IRg = Irrigation - } \\
\text { Rainfall, } \mathbf{m}^{\mathbf{3}} \mathbf{h a}^{-\mathbf{1}}\end{array} \\
2017 / 2018\end{array}$} & \multirow[t]{2}{*}{$\begin{array}{c}\text { Observed Water Productivity } \\
\text { kg grain }^{-3} \mathrm{~m}^{-3} \text { water }\end{array}$} & \multirow[t]{2}{*}{$\begin{array}{c}\text { Simulated Water Productivity, } \\
\mathrm{kg}_{\text {grain }} \mathrm{m}^{-3} \text { water }\end{array}$} & \multirow{2}{*}{$\begin{array}{c}\% \text { Difference }=[(\text { DWFF } \\
- \text { IW }) / \text { IW }] \times 100\end{array}$} \\
\hline & & & & & & & & & \\
\hline Water guality & DWFF & & $3.9 \mathrm{a}$ & \pm 0.4 & & 2680 & 1.46 & & 14.7 \\
\hline Water quality & IW & & $3.4 \mathrm{~b}$ & \pm 0.5 & & 2680 & 1.27 & & \\
\hline \multicolumn{2}{|c|}{ LSD at $\alpha 0.05$} & \multicolumn{3}{|c|}{0.1242} & & & & & \\
\hline \multirow{4}{*}{$\mathrm{N}$-fertigation } & $100 \% \mathrm{~N}$ & & $4.0 \mathrm{a}$ & \pm 0.2 & & 2680 & 1.49 & & \\
\hline & $80 \% \mathrm{~N}$ & & $4.0 \mathrm{a}$ & \pm 0.2 & & 2680 & 1.49 & & \\
\hline & $60 \% \mathrm{~N}$ & & $3.5 \mathrm{~b}$ & \pm 0.2 & & 2680 & 1.31 & & \\
\hline & $40 \% \mathrm{~N}$ & & $3.0 \mathrm{c}$ & \pm 0.5 & & 2680 & 1.12 & & \\
\hline \multicolumn{2}{|c|}{ LSD at $\alpha 0.05$} & \multicolumn{3}{|c|}{0.2035} & & & & & \\
\hline \multirow{8}{*}{ Interaction } & DWFF $\times 100 \% \mathrm{~N}$ & 0.33 & 4.1 & \pm 0.2 & 4.3 & 2680 & 1.53 & 1.60 & 5.1 \\
\hline & DWFF $\times 80 \% \mathrm{~N}$ & 0.33 & 4.2 & \pm 0.1 & 4.0 & 2680 & 1.57 & 1.49 & 10.5 \\
\hline & DWFF $\times 60 \% \mathrm{~N}$ & 0.32 & 3.7 & \pm 0.1 & 3.6 & 2680 & 1.38 & 1.34 & 12.1 \\
\hline & DWFF $\times 40 \% \mathrm{~N}$ & 0.31 & 3.4 & \pm 0.2 & 3.3 & 2680 & 1.27 & 1.23 & 25.9 \\
\hline & $\mathrm{IW} \times 100 \% \mathrm{~N}$ & 0.32 & 3.9 & \pm 0.1 & 3.8 & 2680 & 1.46 & 1.42 & \\
\hline & $\mathrm{IW} \times 80 \% \mathrm{~N}$ & 0.31 & 3.8 & \pm 0.1 & 3.9 & 2680 & 1.42 & 1.46 & \\
\hline & $\mathrm{IW} \times 60 \% \mathrm{~N}$ & 0.31 & 3.3 & \pm 0.1 & 3.5 & 2680 & 1.23 & 1.31 & \\
\hline & $\mathrm{IW} \times 40 \% \mathrm{~N}$ & 0.27 & 2.7 & \pm 0.4 & 2.8 & 2680 & 1.01 & 1.04 & \\
\hline \multicolumn{2}{|c|}{ LSD at $\alpha 0.05$} & \multicolumn{3}{|c|}{ N.S } & & & & & \\
\hline \multirow{3}{*}{ Water quality } & & & & & & $2018 / 2019$ & & & \\
\hline & DWFF & & 4.2 & \pm 0.4 & & 2600 & 1.62 & & 20.0 \\
\hline & IW & & 3.5 & \pm 0.6 & & 2600 & 1.35 & & \\
\hline \multicolumn{2}{|c|}{ LSD at $\alpha 0.05$} & \multicolumn{3}{|c|}{0.147} & & & & & \\
\hline \multirow{4}{*}{$\mathrm{N}$-fertigation } & $100 \% \mathrm{~N}$ & & 4.3 & \pm 0.2 & & 2600 & 1.65 & & \\
\hline & $80 \% \mathrm{~N}$ & & 4.2 & \pm 0.3 & & 2600 & 1.62 & & \\
\hline & $60 \% \mathrm{~N}$ & & 3.7 & \pm 0.3 & & 2600 & 1.42 & & \\
\hline & $40 \% \mathrm{~N}$ & & 3.1 & \pm 0.6 & & 2600 & 1.19 & & \\
\hline \multicolumn{2}{|c|}{ LSD at $\alpha 0.05$} & \multicolumn{3}{|c|}{0.2067} & & & & & \\
\hline \multirow{9}{*}{ Interaction } & DWFF $\times 100 \% \mathrm{~N}$ & 0.34 & 4.5 & \pm 0.1 & 4.7 & 2600 & 1.73 & 1.81 & 9.8 \\
\hline & DWFF $\times 80 \% \mathrm{~N}$ & 0.34 & 4.5 & \pm 0.1 & 4.6 & 2600 & 1.73 & 1.77 & 15.4 \\
\hline & DWFF $\times 60 \% \mathrm{~N}$ & 0.33 & 4.0 & \pm 0.1 & 3.7 & 2600 & 1.54 & 1.42 & 17.6 \\
\hline & DWFF $\times 40 \% \mathrm{~N}$ & 0.32 & 3.6 & \pm 0.2 & 3.4 & 2600 & 1.38 & 1.31 & 33.3 \\
\hline & $\mathrm{IW} \times 100 \% \mathrm{~N}$ & 0.33 & 4.1 & \pm 0.1 & 4.4 & 2600 & 1.58 & 1.69 & \\
\hline & $\mathrm{IW} \times 80 \% \mathrm{~N}$ & 0.32 & 3.9 & \pm 0.2 & 4.0 & 2600 & 1.50 & 1.54 & \\
\hline & $\mathrm{IW} \times 60 \% \mathrm{~N}$ & 0.31 & 3.4 & \pm 0.1 & 3.3 & 2600 & 1.31 & 1.27 & \\
\hline & $\mathrm{IW} \times 40 \% \mathrm{~N}$ & 0.26 & 2.7 & \pm 0.4 & 2.5 & 2600 & 1.04 & 0.96 & \\
\hline & LSD at $\alpha 0.05$ & & & & & & & & \\
\hline
\end{tabular}

$\mathrm{N}$ : fertigation rates of nitrogen; IW: fresh irrigation water; DWFF: drainage water from fish farms. 


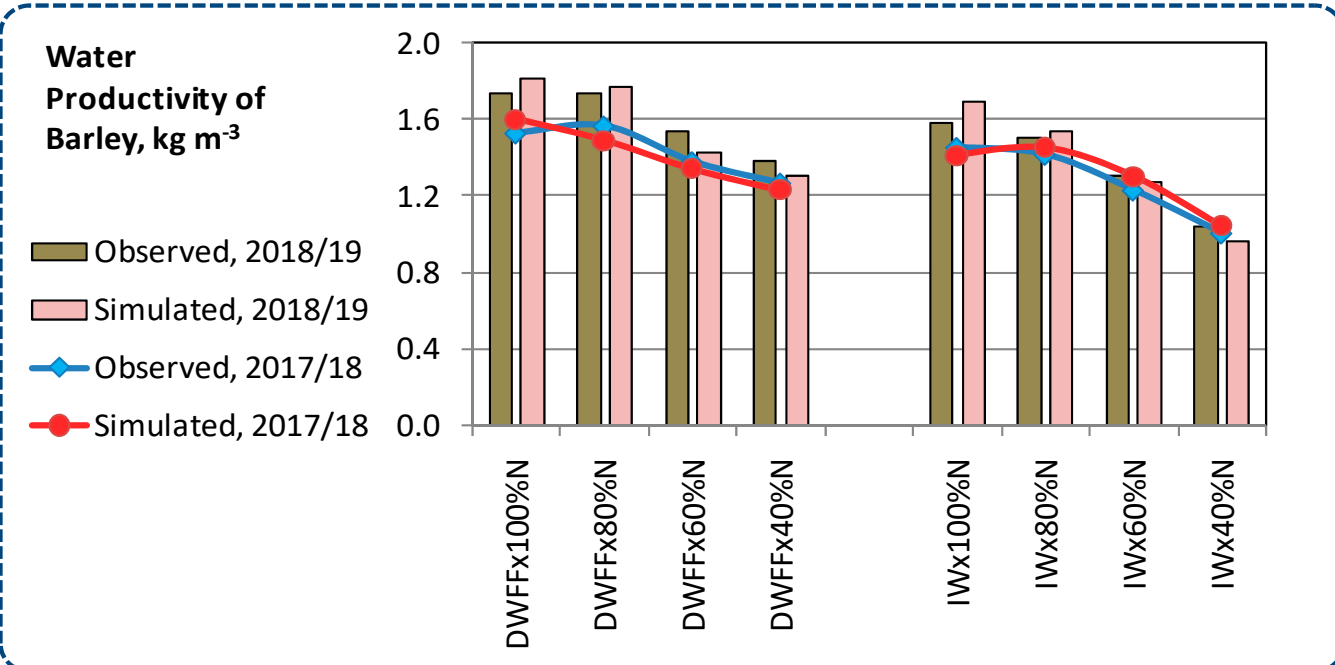

Figure 16. Effect of water quality types and nitrogen fertigation rate on the observbed and simulated water productivity of barley for the 2017/2018 and 2018/2019 seasons for all treatments: drainage water from fish farms(DWFF); fresh irrigation water (IW) and nitrogen (N).

There was a positive effect on the $\mathrm{WP}_{\text {barley, }}$ with an increased $\mathrm{N}$-fertilization rate when using both DWFF and IW in both seasons: 2017/2018 and 2018/2019. The $\mathrm{WP}_{\text {barley }}$ under the DWFF treatments were higher than those under the IW treatments for the two growing seasons: 2017/2018 and 2018/2019.

The highest values of $W_{\text {barley }}$ were 1.57 and $1.73 \mathrm{~kg} \mathrm{~m}^{-3}$ for the DWFF $+80 \% \mathrm{~N}$ treatment for the $2017 / 2018$ and 2018/2019 seasons, respectively. This isdue to the highest productivity under the same conditions (DWFF $+80 \% \mathrm{~N}$ ) and the stability of the amount of IW added to the same growing season.

There was a strong correlation between the observed and the simulation barley water productivity values, with an $\mathrm{R}^{2}$ value of 0.919 for all treatments during the two barley growth seasons (Figure 17).

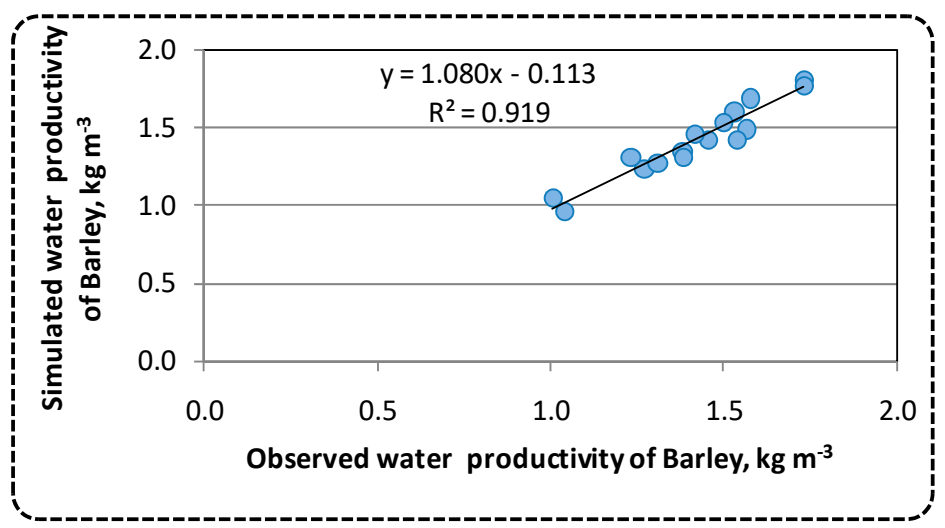

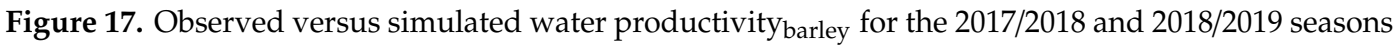
for all treatments.

\section{Conclusions}

This pilot study investigated the suitability and optimization of irrigation using DWFF and IW for barley production through a field study using the SALTMED model.

The WAE increased under irrigation with DWFF compared to IW, which was likely due to the increase in the OM added with the DWFF to sandy soil, keeping the water in the root zone. WAE decreased by decreasing the fertigation rate of nitrogen, and this was likely due to an increase in the size of the roots of plants as a consequence of increasing the fertigation rate, enabling the absorbtion of most of the added IW and fertilizers. Total N uptake was improved with the use of DWFF compared 
with IW for the irrigation of barley during the 2017/2018 and 2018/2019 growing seasons. This is likely due to the presence of additional biological $\mathrm{N}$ in addition to other nutrients that were already present in the DWFF. The total $\mathrm{N}$ uptake has been increased by increasing the $\mathrm{N}$-fertigation rate and this seems logical, as increasing the rate of $\mathrm{N}$-fertigation increases the concentration in the root zone and increases $\mathrm{N}$ uptake.

The obtained results indicate that there was a positive effect with increasing the rate of N-fertilization with irrigation water on crop yield using DWFF and IW in both seasons. However, the yield with irrigation using DWFF was higher than the yield under the IW treatment, for which the percentage increase in productivity ranked between 5.1\% and 25.9\% in 2017/2018 and between $9.8 \%$ and $33.3 \%$ in $2018 / 2019$. The biggest difference was found for the treatment with the least nitrogen. Of note is an additional amount of dissolved nitrogen inherent in DWFF (12.81 $\mathrm{kg} \mathrm{N} \mathrm{ha}^{-1}$ in 2017/2018 and $12.43 \mathrm{~kg} \mathrm{~N} \mathrm{ha}^{-1}$ in 2018/2019) along with more phosphorous and potassium. These findings are in agreement with the results of other reports that show that the integrated cultivation of rice and fish is environmentally sound and healthy, as fish farming improves soil quality and fertility by increasing the availability of $\mathrm{N}$ and phosphorous. In general, crop yields and total $\mathrm{N}$ uptake increased by increasing the rate of nitrogen fertilization. There was a positive impact on the $\mathrm{WP}_{\text {barley }}$ by increasing the fertigation rate under the DWFF and IW treatments in both

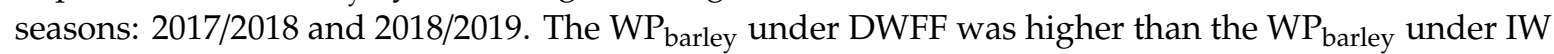
for two seasons: $2017 / 2018$ and 2018/2019. The highest values of $W_{\text {barley }}$ were 1.57 and $1.73 \mathrm{~kg} \mathrm{~m}^{-3}$ for $2017 / 2018$ and $2018 / 2019$, respectively, which occurred under DWFF $+80 \% \mathrm{~N}$. This may be due to the highest productivity under the same conditions (DWFF $+80 \% \mathrm{~N}$ ) and the stability of the amount of IW added to the same growing season.

In summary, the SALTMED model simulated soil moisture, $\mathrm{WA}_{\mathrm{E}}, \mathrm{N}$ concentration within the barley plant root zone for sandy soil, $\mathrm{N}$ uptake, the weight of barley dry matter, and the productivity and water productivity of the barley crop and their $\mathrm{R}^{2}$ values were $0.94,0.89,0.99,0.916,0.89,0.915$, and 0.919 , respectively. The results obtained from the field study and the modeling data indicated that the yield from the use of DWFF has many benefits, which include improving yields and limiting the excessive use of mineral chemical fertilizers. These benefits have increased the income of ordinary farmers, in addition to reducing the volume of wastewater that must be disposed of in local sewage networks. Therefore, this study recommends the use fish culture wastewater for irrigation as a suitable alternative or supplement to limited freshwater resources and as a vital alternative to fertilization.

Author Contributions: Data curation, A.R.E.; Investigation, A.R.E.; Software, A.E.-S., I.A.A., A.A., and M.E.-Z.; Writing-original draft preparation, A.R.E.; Writing-review and editing, A.R.E., I.A.A., A.A., and M.E.-Z. All authors have read and agreed to the published version of the manuscript.

Funding: This research received no external funding.

Acknowledgments: The authors extent their appreciation to the Researchers Supporting Project Number (RSP-2020/176), king Saud University, Riyadh, Saudi Arabia.

Conflicts of Interest: The authors declare no conflict of interest.

\section{References}

1. Hozayn, M.; Abdallha, M.M.; Abd, E.M.A.A.; El Saady, A.A.; Darwish, M.A.; Hozayn, M.; Abdallha, M.M.; Abd, E.M.A.A.; El Saady, A.A.; Darwish, M.A. Applications of magnetic technology in agriculture: A novel tool for improving crop productivity (1): Canola. Afr. J. of Agric. Res. 2016, 11, 441-449. [CrossRef]

2. Abdelraouf, R.; Abuarab, M. Effect of irrigation frequency under hand move lateral and solid set sprinkler irrigation on water use efficiency and yield of wheat. J. Appl. Sci. Res. 2012, 5445-5458.

3. Abdelraouf, R.; El-Shawadfy, M.; Fadl, A.; Bakr, B. Effect of deficit irrigation strategies and organic mulching on yield, water productivity and fruit quality of navel orange under arid regions conditions. Plant Arch. 2020, 20, 3505-3518. 
4. El-Metwally, I.M.; Abdelraouf, R.E.; Ahmed, M.A.; Mounzer, O.; Alarcón, J.J.; Abdelhamid, M.T. Response of Wheat (Triticum aestivum L.) Crop And Broad-Leaved Weeds To Different Water Requirements And Weed Management In Sandy Soils. Agriculture (Polnohospodárstvo) 2015, 61, 22-32. [CrossRef]

5. Abdelraouf, R.; El Habbasha, S.; Taha, M.; Refaie, K. Effect of irrigation water requirements and fertigation levels on growth, yield and water use efficiency in wheat. Middle-East J. Sci. Res. 2013, 16, 441-450.

6. Bakry, A.; Abdelraouf, R.; Ahmed, M.; El-Karamany, M. Effect of drought stress and ascorbic acid foliar application on productivity and irrigation water use efficiency of wheat under newly reclaimed sandy soil. J. Appl. Sci. Res. 2012, 4552-4558.

7. Eid, A.R.; Negm, A. Improving Agricultural Crop Yield and Water Productivity via Sustainable and Engineering Techniques. In The Handbook of Environmental Chemistry; Springer International Publishing: Berlin, Germany, 2018.

8. Abd El-Baset, M.M.; Eid, A.R.; Wahba, S.; El-Bagouri, K.; El-Gindy, A.-G. Scheduling Irrigation using automatic tensiometers for pea crop. Agric. Eng. Int. CIGR J. 2018, 19, 174-183.

9. Hozayn, M.; El Monem, A.A.A.; Abdelraouf, R.E.; Abdalla, M.M. Do Magnetic Water Affect Water Use Efficiency, Quality and Yield of Sugar Beet (Beta vulgaris L.) Plant under Arid Regions Conditions? J. Agron. 2013, 12, 1-10. [CrossRef]

10. Abdel-Shafy, H.I.; El-Saharty, A.A.; Regelsberger, M.; Platzer, C. Rainwater in Egypt: Quantity, distribution and harvesting. Mediterr. Mar. Sci. 2010, 11, 245. [CrossRef]

11. El-Habbasha, S.; Okasha, E.; Abdelraouf, R.; Mohammed, A. Effect of pressured irrigation systems, deficit irrigation and fertigation rates on yield, quality and water use efficiency of groundnut. Int. J. ChemTech Res 2014, 7, 475-487.

12. Abdelraouf, R.; Abou-Hussein, S.; Abd-Alla, A.; Abdallah, E. Effect of short irrigation cycles on soil moisture distribution in root zone, fertilizers use efficiency and productivity of potato in new reclaimed lands. J. Appl. Sci. Res. 2012, 3823-3833.

13. Abdelraouf, R.; Abou-Hussein, S.; Refaie, K.; El-Metwally, I. Effect of pulse irrigation on clogging emitters, application efficiency and water productivity of potato crop under organic agriculture conditions. Aust. J. Basic and Appl. Sci. 2012, 6, 807-816.

14. Molden, D. Water for Food Water for Life: A Comprehensive Assessment of Water Management in Agriculture; Routledge: London, UK, 2013.

15. Altieri, M.A. Linking ecologists and traditional farmers in the search for sustainable agriculture. Front. Ecol. Environ. 2004, 2, 35-42. [CrossRef]

16. Xie, J.; Hu, L.; Tang, J.; Wu, X.; Li, N.; Yuan, Y.; Yang, H.; Zhang, J.; Luo, S.; Chen, X. Ecological mechanisms underlying the sustainability of the agricultural heritage rice-fish coculture system. Proc. Natl. Acad. Sci. USA 2011, 108, E1381-E1387. [CrossRef] [PubMed]

17. Hu, L.; Zhang, J.; Ren, W.; Guo, L.; Cheng, Y.; Li, J.; Li, K.; Zhu, Z.; Zhang, J.; Luo, S. Can the co-cultivation of rice and fish help sustain rice production? Sci. Rep. 2016, 6, 28728. [CrossRef]

18. Bostock, J.; McAndrew, B.; Richards, R.; Jauncey, K.; Telfer, T.; Lorenzen, K.; Little, D.; Ross, L.; Handisyde, N.; Gatward, I.; et al. Aquaculture: Global status and trends. Philos. Trans. R. Soc. B Biol. Sci. 2010, 365, 2897-2912. [CrossRef] [PubMed]

19. Walia, S.; Kaur, N. Integrated Farming System-An Ecofriendly Approach for Sustainable Agricultural Environment-A Review. Greener J. Agron. For. Hortic. 2013, 1, 1-11. [CrossRef]

20. FAO. State of World Aquaculture 2006; FAO Fisheries and Aquaculture Technical Papers Food and Agriculture Organisation of the United Nations: Rome, Italy, 2006; Volume 500.

21. Van der Heijden, P.; Nasr Alla, A.; Kenawy, D. Water Use at Integrated Aquaculture-Agriculture Farms: Experiences with Limited Water Resources in Egypt; Global Aquaculture Alliance: Portsmouth, NH, USA, 2012.

22. Boelee, E. Managing Water and Agroecosystems for Food Security; CABI: Wallingford, UK, 2013; Volume 10.

23. Adámek, Z.; Linhart, O.; Kratochvíl, M.; Flajšhans, M.; Randák, T.; Policar, T.; Kozák, P. Aquaculture in the Czech Republic in 2012: A prosperous and modern European sector based on a thousand-year history of pond culture. World Aquac. 2012, 43, 20.

24. Lee, C.; Schaaf, T. The Future of Drylands. In Proceedings of the International Scientific Conference on Desertification and Drylands Research, Tunis, Tunisia, 19-21 June 2006; Springer Science \& Business Media: Berlin, Germany, 2008. 
25. Ragab, R.; Battilani, A.; Matovic, G.; Stikic, R.; Psarras, G.; Chartzoulakis, K. SALTMED Model as an Integrated Management Tool for Water, Crop, Soil and N-Fertilizer Water Management Strategies and Productivity: Field and Simulation Study. Irrig. Drain. 2015, 64, 13-28. [CrossRef]

26. Ragab, R.; Malash, N.; Gawad, G.A.; Arslan, A.; Ghaibeh, A. A holistic generic integrated approach for irrigation, crop and field management: 1 . The SALTMED model and its calibration using field data from Egypt and Syria. Agric. Water Manag. 2005, 78, 67-88. [CrossRef]

27. Pulvento, C.; Riccardi, M.; Lavini, A.; D'Andria, R.; Ragab, R. Parameterization and Field Validation of Saltmed Model for Grain Amaranth Tested in South Italy. Irrig. Drain. 2015, 64, 59-68. [CrossRef]

28. Rameshwaran, P.; Tepe, A.; Yazar, A.; Ragab, R. Effects of drip-irrigation regimes with saline water on pepper productivity and soil salinity under greenhouse conditions. Sci. Hortic. 2016, 199, 114-123. [CrossRef]

29. Rameshwaran, P.; Qadir, M.; Ragab, R.; Arslan, A.; Majid, G.A.; Abdallah, K. Tolerance of faba bean, chickpea and lentil to salinity: Accessions' salinity response functions. Irrig. Drain. 2016, 65, 49-60. [CrossRef]

30. Rameshwaran, P.; Tepe, A.; Yazar, A.; Ragab, R. The Effect of Saline Irrigation Water on the Yield of Pepper: Experimental and Modelling Study. Irrig. Drain. 2014, 64, 41-49. [CrossRef]

31. Fghire, R.; Wahbi, S.; Anaya, F.; Issa Ali, O.; Benlhabib, O.; Ragab, R. Response of Quinoa to Different Water Management Strategies: Field Experiments and Saltmed Model Application Results. Irrig. Drain. 2015, 64, 29-40. [CrossRef]

32. Ince Kaya, Ç.; Yazar, A. Saltmed Model Performance for Quinoa Irrigated with Fresh and Saline Water in a Mediterranean Environment. Irrig. Drain. 2016, 65, 29-37. [CrossRef]

33. Aly, A.A.; Al-Omran, A.M.; Khasha, A.A. Water management for cucumber: Greenhouse experiment in Saudi Arabia and modeling study using SALTMED model. J. Soil Water Conserv. 2015, 70, 1-11. [CrossRef]

34. Arslan, A.; Majid, G.A.; Abdallah, K.; Rameshwaran, P.; Ragab, R.; Singh, M.; Qadir, M. Evaluating the Productivity Potential of Chickpea, Lentil and Faba Bean Under Saline Water Irrigation Systems. Irrig. Drain. 2016, 65, 19-28. [CrossRef]

35. Abdelraouf, R.E.; Ragab, R. Applying partial root drying drip irrigation in the presence of organic mulching. Is that the best irrigation practice for arid regions? Field and modelling study using the saltmed model. Irrig. Drain. 2018, 67, 491-507. [CrossRef]

36. Abdelraouf, R.E.; Ragab, R. Effect of Fertigation Frequency and Duration on Yield and Water Productivity of Wheat: Field and Modelling Study Using the Saltmed Model. Irrig. Drain. 2018, 67, 414-428. [CrossRef]

37. Abdelraouf, R.E.; Ragab, R. Is the Partial Root Drying Irrigation Method Suitable for Sandy Soils? Field Experiment and Modelling Using the Saltmed Model. Irrig. Drain. 2018, 67, 477-490. [CrossRef]

38. Allen, R.G.; Pereira, L.S.; Raes, D.; Smith, M. Guidelines for computing crop water requirements. Irrig. Drain. Pap. 1998, 56, 300.

39. Snedecor, G.; Cochran, W. Statistical Methods, 7th ed.; Iowa State University Press: Iowa City, IW, USA, 1982.

40. Steel, R.G.; Torrie, J.H. Principles and Procedures of Statistics, a Biometrical Approach; McGraw-Hill Kogakusha, Ltd.: New York, NY, USA, 1980.

41. Silva, L.L.; Ragab, R.; Duarte, I.; Lourenço, E.; Simões, N.; Chaves, M.M. Calibration and validation of SALTMED model under dry and wet year conditions using chickpea field data from Southern Portugal. Irrig. Sci. 2012, 31, 651-659. [CrossRef]

42. Rameshwaran, P.; Tepe, A.; Yazar, A.; Ragab, R. The effect of saline irrigation water on the yield of pepper: Experimental and modelling study. Irrig. Drain. 2015, 64, 41-49. [CrossRef]

43. Dugan, P.; Dey, M.M.; Sugunan, V.V. Fisheries and water productivity in tropical river basins: Enhancing food security and livelihoods by managing water for fish. Agric. Water Manag. 2006, 80, 262-275. [CrossRef]

44. Giap, D.H.; Yi, Y.; Lin, C.K. Effects of different fertilization and feeding regimes on the production of integrated farming of rice and prawn Macrobrachium rosenbergii (De Man). Aquac. Res. 2005, 36, 292-299. [CrossRef]

Publisher's Note: MDPI stays neutral with regard to jurisdictional claims in published maps and institutional affiliations.

(C) 2020 by the authors. Licensee MDPI, Basel, Switzerland. This article is an open access article distributed under the terms and conditions of the Creative Commons Attribution (CC BY) license (http://creativecommons.org/licenses/by/4.0/). 